\title{
Hepatitis E Virus Infection: Circulation, Molecular Epidemiology, and Impact on Global Health
}

\author{
Srinivas Reddy Pallerla ${ }^{1,2,+}\left(\mathbb{D}\right.$, Dominik Harms ${ }^{3,+}{ }^{\text {, Reimar Johne }}{ }^{4}\left(\mathbb{D}\right.$, Daniel Todt ${ }^{5,6}{ }^{(\mathbb{C})}$, \\ Eike Steinmann ${ }^{5}$, Mathias Schemmerer ${ }^{7}{ }^{\circledR}$, Jürgen J. Wenzel ${ }^{7}{ }^{\circledR}$, Jörg Hofmann ${ }^{8}$, \\ James Wai Kuo Shih ${ }^{9}$, Heiner Wedemeyer ${ }^{10,11}$, C.-Thomas Bock ${ }^{1,3, *, \pm}$ and \\ Thirumalaisamy P. Velavan $1,2,12, \ddagger$ (D) \\ 1 Institute of Tropical Medicine, University of Tübingen, 72074 Tübingen, Germany; \\ srinivas-reddy.pallerla@uni-tuebingen.de (S.R.P.); velavan@medizin.uni-tuebingen.de (T.P.V.) \\ 2 Vietnamese-German Center for Medical Research (VG-CARE), Hanoi 100000, Vietnam \\ 3 Division of Viral Gastroenteritis and Hepatitis Pathogens and Enteroviruses, Department of Infectious \\ Diseases, Robert Koch Institute, 13353 Berlin, Germany; HarmsD@rki.de \\ 4 Unit Viruses in Food, Department Biological Safety, German Federal Institute for Risk Assessment, \\ 10589 Berlin, Germany; Reimar.Johne@bfr.bund.de \\ 5 Department of Molecular and Medical Virology, Ruhr University Bochum, 44801 Bochum, Germany; \\ daniel.todt@ruhr-uni-bochum.de (D.T.); eike.steinmann@ruhr-uni-bochum.de (E.S.) \\ 6 European Virus Bioinformatics Center (EVBC), 07743 Jena, Germany \\ 7 Institute of Clinical Microbiology and Hygiene, National Consultant Laboratory for HAV and HEV, \\ University Medical Center Regensburg, 93053 Regensburg, Germany; \\ Mathias.Schemmerer@klinik.uni-regensburg.de (M.S.); juergen.wenzel@klinik.uni-regensburg.de (J.J.W.) \\ 8 Institute of Virology, Charité Universitätsmedizin Berlin, Labor Berlin-Charité-Vivantes GmbH, \\ 13353 Berlin, Germany; Joerg.Hofmann@laborberlin.com \\ 9 Xiamen Innovax Biotech Co., Ltd., Haicang, Xiamen 361022, China; jwshih@innovax.cn \\ 10 Department of Gastroenterology, Hepatology and Endocrinology, Hannover Medical School, \\ 30623 Hannover, Germany; Wedemeyer.heiner@mh-hannover.de \\ 11 German Center for Infection Research, Partner Hannover-Braunschweig, 38124 Braunschweig, Germany \\ 12 Faculty of Medicine, Duy Tan University, Da Nang 550000, Vietnam \\ * Correspondence: BockC@rki.de; Tel.: +49-30-18754-2617 \\ + S.R.P. and D.H. contributed equally to the work and thus share first authorship. \\ $\ddagger \quad$ C.-T.B. and T.P.V. contributed equally to the work and thus share last authorship.
}

Received: 22 September 2020; Accepted: 16 October 2020; Published: 20 October 2020

check for updates

\begin{abstract}
Infection with hepatitis E virus (HEV) represents the most common source of viral hepatitis globally. Although infecting over 20 million people annually in endemic regions, with major outbreaks described since the 1950s, hepatitis E remains an underestimated disease. This review gives a current view of the global circulation and epidemiology of this emerging virus. The history of HEV, from the first reported enteric non-A non-B hepatitis outbreaks, to the discovery of the viral agent and the molecular characterization of the different human pathogenic genotypes, is discussed. Furthermore, the current state of research regarding the virology of HEV is critically assessed, and the challenges towards prevention and diagnosis, as well as clinical risks of the disease described. Together, these points aim to underline the significant impact of hepatitis $\mathrm{E}$ on global health and the need for further in-depth research to better understand the pathophysiology and its role in the complex disease manifestations of HEV infection.
\end{abstract}

Keywords: hepatitis E; infection; outbreak; epidemiology; global health 


\section{Introduction}

Hepatitis E virus (HEV) is a quasi-enveloped, positive strand RNA virus belonging to the family Hepeviridae [1]. HEV is the causative agent of Hepatitis E, the most common cause of acute viral hepatitis both in resource poor and developed countries. Hepatitis E presents as a mostly asymptomatic or acute self-limiting disease with a mortality rate up to $3 \%$ in young adults [2]. However the mortality rate may reach $30 \%$ in pregnant women [3]. Furthermore, chronic hepatitis E infections may occur in high-risk groups such as immunocompromised individuals (e.g., transplant recipients), those with pre-existing liver disease, HIV-positive persons, and cancer patients [4-7]. A recent study estimates that 939 million people worldwide have been infected with HEV in the past and that 15-110 million people have recent or ongoing infections [8]. According to the WHO, an estimated 3.3 million symptomatic hepatitis E cases occur each year in endemic areas with 44,000 related deaths [9].

HEV belongs to the genus Orthohepevirus, containing four species, namely Orthohepevirus $A, B$, $C$, and $D$ with $A$ containing the genotypes HEV-1 to HEV-8 [10]. The genotypes that infect humans include HEV-1 to $-4,-7$, and Orthohepevirus $C$, casually termed rat HEV [10-13]. HEV-1 and -2 infect only humans and cause large waterborne outbreaks due to contaminated drinking water in endemic regions of South and Southeast Asia, Africa, and Mexico [14]. HEV-3 and -4 infect both humans and animals, cause sporadic cases in developed countries, and are mainly spread through consumption or close contact with contaminated animal products [14,15]. HEV-7 and rat HEV infections are rarely reported. HEV-1 is mainly transmitted via the fecal-oral route, but also by vertical transmission from mother to child, from person to person, and by blood transfusions [14,16]. HEV-2 is transmitted via the fecal-oral route and human-to-human [14]. In contrast, HEV-3 and -4 are transmitted by transfusion of contaminated blood products, consuming contaminated shellfish, contact with infected animals, environmental contamination by animal manure run-off, and consumption of raw or undercooked meat $[14,16]$. Hepatitis $E$ is not a sole health burden of the developing world, however, with numbers of reported sporadic cases increasing in industrialized nations, where the virus is spread primarily through zoonotic transmission.

Although usually a self-limiting disease in immunocompetent persons, hepatitis E can cause serious complications in at-risk populations such as pregnant women [17] and organ transplant recipients $[5,18,19]$. Treatment options remain limited, and only one vaccine has been developed so far with its use limited to China [20].

This review focuses on the history and discovery of the hepatitis E virus and discusses reported outbreaks in order to share new aspects and insights into its epidemiology and global circulation. Furthermore, it explores studies on the virology of HEV to portray a detailed picture of the known stages of the viral life cycle. Finally, it briefly summarizes the clinical aspects to underline the significant need for further research into the viral pathophysiology contributing to this underrated emerging infectious disease.

\section{Discovery and History}

An epidemic of HEV was reported in 1955 in Delhi, India, with about 29,000 cases of icteric hepatitis [21]. After this epidemic, several waterborne outbreaks were reported throughout India, and most of these cases were non- $\mathrm{A}$ and non-B, leading the disease to be described as enteric non- $\mathrm{A}$ non-B hepatitis (ENANBH) [21]. In addition, a major water-related epidemic outbreak in the Kashmir Valley was reported at the end of 1978, with 52,000 cases and 1700 deaths [22,23]. The symptoms of these cases were similar to hepatitis A but were negative for both hepatitis A and hepatitis B and were therefore confirmed as ENANBH [22]. In 1981, hepatitis occurred in a Soviet military camp in Afghanistan. To investigate this situation, a doctor in the Russian army, Mikhail Balayan, voluntarily ingested a pooled filtrate of stool samples from the infected soldiers, and he subsequently developed acute hepatitis [24]. The serum of Dr. Balayan was negative for hepatitis A virus (HAV) and hepatitis $B$ virus (HBV), suggesting that a new pathogen was responsible for this infection. Immunoelectron microscopy identified 20-30 nm non-enveloped virus-like particles in stool, confirming a novel 
ENANBH virus [24]. In 1990, this novel ENANBH was partially cloned and sequenced and was henceforth called the hepatitis E virus (HEV) [25,26]. It was initially indicated that hepatitis E infection spreads via contaminated water and is limited to resource poor countries. Later, however, increasing reports of sporadic cases emerged in non-endemic industrialized countries with high seroprevalence in a few areas of the United States [27]. The reason for this high prevalence was not understood, and it was speculated that undetected non-pathogenic or less pathogenic HEV strains were circulating. In 1998, genome sequences confirmed that human HEV were similar to that of HEV in pigs, suggesting zoonotic transmission pathways [28,29]. Overall, these studies led to the identification of a broad spectrum of HEV strains that are either restricted to humans, animals, or infect both.

\section{Virology}

HEV particles have an icosahedral shape, are non-enveloped, and form virions with a diameter of about 27-34 nm [30]. The HEV genome is about $7.2 \mathrm{~kb}$ in size and consists of a $5^{\prime}$ UTR capped with 7-methylguanosine $\left(\mathrm{M}^{7} \mathrm{G}\right)$, followed by three open reading frames (ORF1, ORF2, and ORF3). The $3^{\prime}$ UTR ends with a poly $(A)$ tail $\left(A_{n}\right)$ like the eukaryotic mRNA structure. Viral replication starts with the translation of the ORF1-encoded non-structural polyprotein. An RNA-dependent RNA polymerase (RdRp) subsequently transcribes the full-length negative-sense RNA. This RNA serves as a template for the synthesis of two viral positive-sense RNAs in infected cells, a full-length genomic RNA, and a subgenomic RNA containing the capsid protein-encoding ORF2 and polyfunctional protein (PP)-encoding ORF3 [31]. The genomic arrangement and the stages of viral genome replication and protein synthesis are visualized in Figure 1.

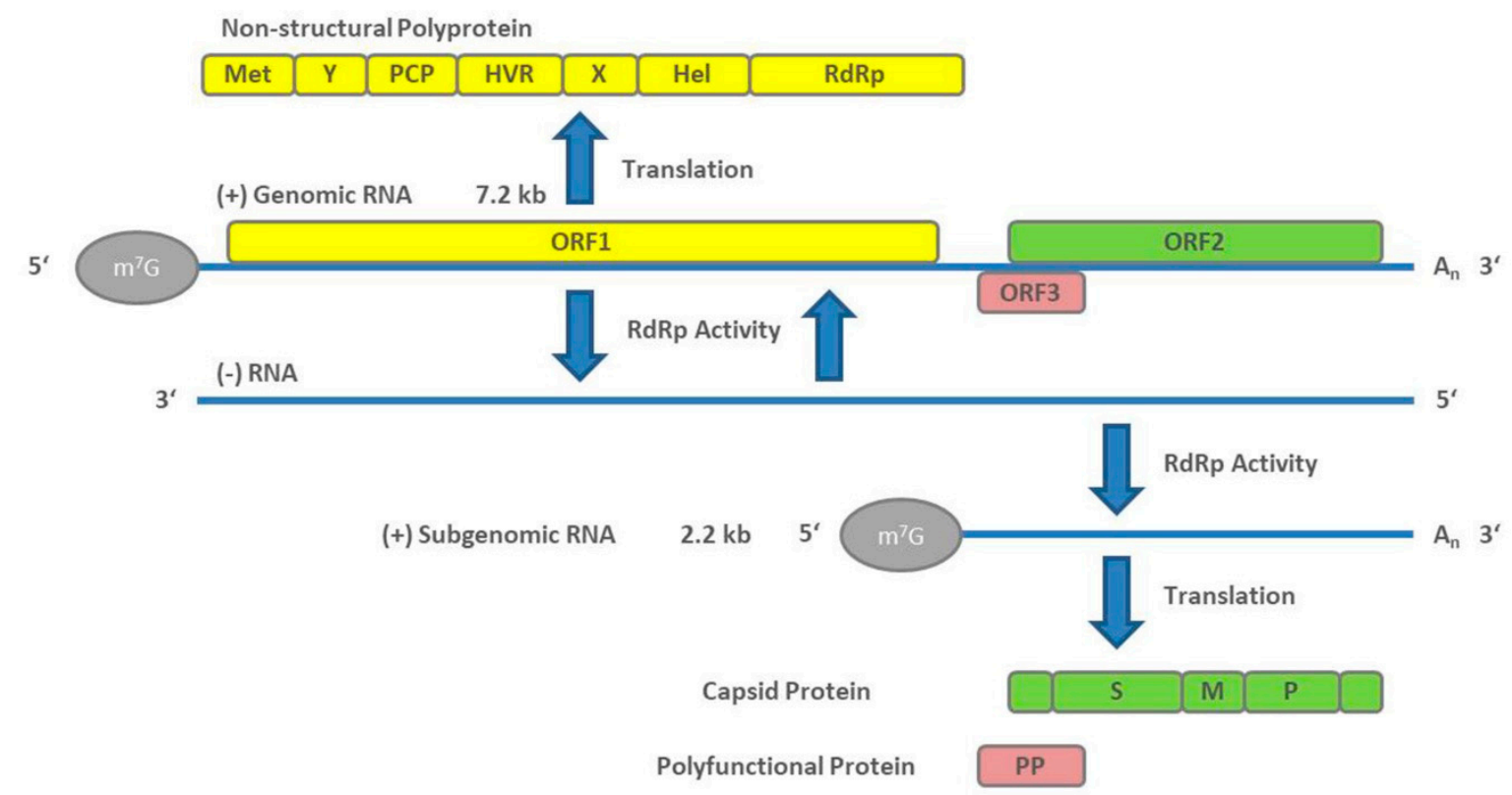

Figure 1. Genome arrangement of hepatitis E virus (HEV) and steps of viral genome replication.

ORF1 encodes a non-structural polyprotein of varying length that consists of seven domains comprising a methyl transferase (Met), X and Y domains, a papain-like cysteine protease (PCP), a proline-rich hypervariable region (HVR), RNA helicase (Hel), and RNA-dependent RNA polymerase (RdRp) [32]. Of these seven, only the Met, Hel, and RdRp have been functionally well characterized [33-36]. The complete function of all ORF1 domains is still not fully understood. In addition, whether it functions as a multi-domain polyprotein like a "Swiss army knife" or whether it needs to be cleaved for functional activity [37] is under debate and there is still no conclusive evidence that PCP has a protease function [38]. Although ORF1 is essential for HEV replication, its HVR 
displays considerable sequence divergence even between isolates of the same virus genotype [39]. Size differences between different HEV genomes can be primarily attributed to the HVR region. Analysis of different patient derived HEV isolates revealed various strains that harbor insertions from other regions of the viral genome, or from human genes, within the HVR [40].

The ORF2 encodes for the capsid protein. Its N-terminal signal peptide shuttles it to the extracellular compartment. The ORF2 protein contains three potential $N$-glycosylation sites [41-43], and is the main immunogenic target of neutralizing antibodies [41,44]. The full-length ORF2 encodes 660aa; however, recent reports suggested that ORF2 protein is processed into at least two forms, including one or two forms of secreted glycoproteins that are not associated with infectious particles, and one unglycosylated form which is the structural component of infectious particles [45,46]. ORF2 has been well characterized for its usefulness in diagnostics and vaccines, including the vaccine Hecolin ${ }^{\circledR}$ p239, which is currently only approved in China.

The ORF3 protein is a polyfunctional 13-kDa protein of 113 (genotype 3) or 114aa (genotypes 1, 2, and 4). Computational homology scans did not reveal any domains comparable to other known viral proteins. It has been shown to bind to microtubules and be involved in particle assembly and egress by interaction with the tumor susceptibility gene 101 protein (TSG101), a key protein involved in the endosomal sorting complexes of the ESCRT (endosomal sorting complexes required to transport) transport pathway and involved in the budding of the viruses [47-50]. Furthermore, it may play a role in infectious particle secretion via its palmitoylation and membrane association [51]. Additionally, there are also reports of its role in intracellular transduction pathways, the potential to reduce host immune responses, and protection of virus-infected cells [52-54]. A recent article reports that ORF3 is a functional ion channel required for release of infectious particles [55].

HEV exists as quasi-enveloped viral particles in blood and cell culture supernatant and as non-enveloped virions in bile and feces [56]. When they are shed into the environment, non-enveloped naked virions are enterically transmitted through contaminated water or food. So far, it is not well understood how HEV virions overcome the intestinal barrier and reach the liver. However, it is assumed that the virions first infect the enterocytes, where they multiply, and are excreted as quasi-enveloped virus particles into blood circulation, thus infecting hepatocytes [57]. On their way through the bile duct, the envelope is stripped off and naked, and more infectious virions are again released via the stool $[56,58]$.

Naked HEV particles possibly attach to target cells via heparin sulfate proteoglycans (HSGPs) [59] and heat shock cognate protein 70 (HSC70) [60]. Integrin $\alpha 3$ has been described recently [61] as a candidate receptor to mediate entry into the cells by dynamin-dependent, clathrin-mediated endocytosis, supported by the GTPases Ras-related proteins Rab5A (RAB5) and Rab7a (RAB7), which are necessary for quasi-enveloped particle internalization $[59,62,63]$. Quasi-enveloped particles attach less efficiently to cells and likely enter the cell in a manner similar to exosomes [63]. Not requiring HSGPs allows attachment in a non-cell-specific manner, possibly explaining HEV's capacity to infect extrahepatic tissues [63]. Following this, lysosomal degradation of the lipid membrane (in the case of enveloped particles) and subsequent viral capsid uncoating take place, followed by release of the genomic HEV positive strand RNA into the cytoplasm [63]. The host cellular transcriptional machinery translates ORF1 polyprotein containing RdRp from HEV RNA. The polymerase transcribes the full-length negative-sense HEV RNA. From this negative strand, two RNAs are transcribed by RNA helicases and RdRp to form a full-length genomic RNA and a $2.2 \mathrm{~kb}$ bicistronic subgenomic RNA. These two capped and polyadenylated RNAs serve as templates for the translation of non-structural ORF1 polyproteins, ORF2 capsid proteins, and polyfunctional ORF3 proteins [64].

The subsequent steps are viral assembly and release. ORF2 and ORF3 and positive-sense genomic HEV RNA are known to form a complex in the ER-Golgi intermediate compartment and produce viral progeny particles $[65,66]$. The particles of the progeny virus bind to the TSG101 protein and are secreted in a presumably basal fashion as enveloped particles $[47,48]$. When leaving hepatocytes from the apical part, the envelope is stripped as described above [56,58]. There are many significant gaps in 
the understanding of the HEV life cycle and virus-host cell interactions [67], and further studies are urgently needed. Several in vitro systems exist to study the virus. Reverse genetics models based on infectious cDNA clones have been described for several genotypes. The most commonly used are the Sar-55-related genotype 1 clone [68], the genotype 3a and 3c Kernow-C1- [69], and 47832-related [70] clones, respectively, both of which contain insertions in the HVR, and the genotype 4 TW6196 clone [71]. A recent presentation of a novel in vitro method to produce high viral titers, allowing study of the full HEV replication cycle in cell culture, has additionally created confidence that we may overcome our limited understanding of HEV pathophysiology [72]. Although these systems are most commonly used in conventional cell culture systems, several animal infection models have been developed. Rhesus monkeys have been shown to be susceptible to HEV-1 through -4 [28,73], while cynomolgous monkeys and chimpanzees have been used as models for HEV-1 and -2 [68,74]. As natural hosts for HEV-3 and -4, pigs can be readily infected by strains of these genotypes [75,76]. Recent reports have also described successful infection of human liver chimeric mice with HEV-1 and -3 strains [77,78]. Moreover, small animal and avian models exist for the study of animal HEV. Although animal infection models provide more physiological conditions than cell culture systems, limitations are also present. Neither non-human primates nor mice represent natural hosts of $\mathrm{HEV}$, while pigs can only be infected with HEV-3 and -4. Experiments with primates also raise ethical concerns.

\section{Outbreaks}

HEV outbreaks occur mainly in resource poor countries, due to waterborne infections caused by HEV-1 and possibly HEV-2 [79], often during the monsoon season. The outbreaks are caused mainly by consumption and use of contaminated water where sanitary and hygienic conditions are poor [14]. The first laboratory confirmed HEV outbreak was reported in Delhi in 1955, and since then several outbreaks have been reported in tropical and subtropical regions of the world, especially in Asian and African countries. Reported outbreaks are summarized in Table 1.

Table 1. Reported HEV outbreaks.

\begin{tabular}{|c|c|c|c|c|}
\hline Year(s) & Country & Mode of Transmission & Reported & Ref. \\
\hline 1955-1956 & India & Waterborne & 29,300 & [80] \\
\hline 1978-1979 & Kashmir & Waterborne & $>270$ & [23] \\
\hline 1980-1981 & Algeria & $\begin{array}{c}\text { Sewage } \\
\text { contamination-river } \\
\text { water }\end{array}$ & 788 & [81] \\
\hline 1982 & Myanmar & Waterborne & 399 & [82] \\
\hline 1983 & Namibia & Waterborne & hundreds & {$[79,83]$} \\
\hline 1983-1984 & Cote d'Ivoire & Waterborne & 623 & [84] \\
\hline 1985 & Turkmenistan & Waterborne & 16,175 & {$[85,86]$} \\
\hline 1985 & Botswana & $\begin{array}{l}\text { Fecal contamination of } \\
\text { water }\end{array}$ & 273 & [87] \\
\hline 1986 & Mexico & $\begin{array}{l}\text { Contaminated well } \\
\text { water }\end{array}$ & $>200$ & [88] \\
\hline 1988 & Somalia & Waterborne & 106 & [89] \\
\hline 1988-1989 & India & $\begin{array}{l}\text { Contaminated drinking } \\
\text { water }\end{array}$ & 53 & [90] \\
\hline 1988-1989 & Ethiopia & After monsoon rains & $>750$ & [91] \\
\hline 1989 & Myanmar & $\begin{array}{l}\text { Contamination-water } \\
\text { supply by feces }\end{array}$ & 93 & [92] \\
\hline 1991 & India & $\begin{array}{l}\text { Contaminated river } \\
\text { water (Ganges) }\end{array}$ & $79,000^{1}$ & [93] \\
\hline
\end{tabular}


Table 1. Cont

\begin{tabular}{|c|c|c|c|c|}
\hline Year(s) & Country & Mode of Transmission & Reported & Ref. \\
\hline 1991 & China & Waterborne & 119,000 & {$[94,95]$} \\
\hline 1991 & Indonesia & Waterborne & $1688^{1}$ & [96] \\
\hline 1993-1994 & Pakistan & Waterborne & 3827 & [97] \\
\hline 1994 & Vietnam & After heavy rains & $>300$ & [98] \\
\hline 1994 & Morocco & $\begin{array}{l}\text { Fecal contamination of } \\
\text { drinking water }\end{array}$ & 73 & [99] \\
\hline 1995-1996 & Namibia & Waterborne & $>600$ & [79] \\
\hline 1998 & India & Waterborne & 82 & [100] \\
\hline 1998 & Indonesia & Waterborne & 472 & [101] \\
\hline 1998 & Pakistan & $\begin{array}{c}\text { Fecal } \\
\text { contamination-water } \\
\text { system }\end{array}$ & 104 & [102] \\
\hline 2002 & India & Contaminated water & 185 & [103] \\
\hline 2004 & $\begin{array}{l}\text { Central African } \\
\text { Republic }\end{array}$ & Rainy season & 213 & [104] \\
\hline 2004 & Sudan & Safe water insufficient & $>2600$ & [105] \\
\hline 2004 & India & $\begin{array}{l}\text { Drinking untreated raw } \\
\text { river water }\end{array}$ & 538 & [106] \\
\hline 2004 & Chad & Waterborne & $1442^{1}$ & [107] \\
\hline 2005 & Iraq & Waterborne & $268^{1}$ & [108] \\
\hline 2005 & India & $\begin{array}{l}\text { Contaminated drinking } \\
\text { water }\end{array}$ & 429 & [109] \\
\hline 2006 & Sudan & Waterborne & 2621 & {$[110,111]$} \\
\hline 2007-2008 & India & $\begin{array}{l}\text { Fecal contamination of } \\
\text { water resources }\end{array}$ & 64 & [112] \\
\hline $2007-2008$ & Egypt & Waterborne & 28 & [113] \\
\hline 2007-2009 & Uganda & Waterborne & 146 & [114] \\
\hline 2008 & India & $\begin{array}{l}\text { Sewage contamination of } \\
\text { the river }\end{array}$ & $23,915^{1}$ & [115] \\
\hline 2008 & Uganda & $\begin{array}{c}\text { Substantial } \\
\text { person-to-person }\end{array}$ & $>10,000$ & [116-118] \\
\hline 2008-2009 & Bangladesh & $\begin{array}{c}\text { Sewage } \\
\text { contamination-municipal } \\
\text { water }\end{array}$ & $4751^{1}$ & [119] \\
\hline 2009-2012 & Uganda & Contaminated water & 987 & [120] \\
\hline 2010 & Bangladesh & Waterborne & 200 & [121] \\
\hline 2010 & India & Waterborne & 102 & [122] \\
\hline 2005-2010 & India & Waterborne & 442 & [123] \\
\hline 2010-2011 & Sudan & Waterborne & 39 & [105] \\
\hline 2012 & India & $\begin{array}{l}\text { Fecal contamination of } \\
\text { drinking water }\end{array}$ & 180 & [124] \\
\hline 2012 & Kenya & Waterborne & 131 & [125] \\
\hline 2008-2012 & $\begin{array}{l}\text { Central African } \\
\text { Republic }\end{array}$ & Waterborne & 745 & [126] \\
\hline $2012-2013$ & South Sudan & Waterborne & $5080^{1}$ & [127] \\
\hline 2013 & India & $\begin{array}{l}\text { Sewage contamination of } \\
\text { drinking water }\end{array}$ & 240 & [128] \\
\hline
\end{tabular}


Table 1. Cont.

\begin{tabular}{ccccc}
\hline Year(s) & Country & Mode of Transmission & Reported & Ref. \\
\hline 2013 & Cameroon & Waterborne & 33 & {$[129]$} \\
\hline $2014-2015$ & Bangladesh & Waterborne & 103 & {$[130]$} \\
\hline $2014-2016$ & India & Waterborne & 17 & {$[131]$} \\
\hline $2016-2017$ & Chad & Waterborne & 1293 & {$[132]$} \\
\hline $2017-2018$ & Nigeria & $\begin{array}{c}\text { Contamination of } \\
\text { drinking water }\end{array}$ & 1376 & {$[133]$} \\
\hline $2014-2017$ & Bangladesh & Waterborne & 661 & {$[134]$} \\
\hline 2018 & $\begin{array}{c}\text { Central African } \\
\text { Republic }\end{array}$ & Waterborne & 149 & {$[135]$} \\
\hline 2018 & South Sudan & Waterborne & 161 & {$[135]$} \\
\hline 2019 & Pakistan & Waterborne & 300 & {$[136]$} \\
\hline $2017-2020$ & Namibia & Waterborne & 7247 & {$[137]$} \\
\hline
\end{tabular}

${ }^{1}$ Numbers based on reported estimates.

The largest outbreaks involved 79,000 ENANBH cases in Kanpur, India, between 1990 and 1991, and 119,000 cases in China between 1986 and 1988 [93-95]. Sporadic outbreaks have also occurred in recent years in Asian and African countries, but with a low number of reported cases [133-137]. Using modelling approaches, a recent study describes the ecologically most suitable hotspots for HEV viruses: the Ganges Valley in India and Pakistan [138]. Important factors contributing to water-related outbreaks of HEV are population density, socio-economic conditions, the level of sanitation, and access to drinking water $[14,138]$. There are also frequent outbreaks in refugee camps, military camps, and emergency shelters in conflict- and catastrophe-affected regions [127,139-142]. In summary, HEV outbreaks can be prevented by improving sanitary conditions and ensuring access to clean drinking water.

\section{Epidemiology}

Taxonomically, the family Hepeviridae is divided into the genus Orthohepevirus with the species Orthohepevirus $A, B, C$, and $D$, and the genus Piscihepevirus. The species Orthohepevirus $A$ contains eight distinct genotypes that infect humans and other mammals [10]. It is known that HEV-1 to -4 infect humans, and rare cases of human infection with other genotypes like HEV-7 have also been described [11,143]. Details on the genotypes of Orthohepevirus $A$ including host range, transmission routes, and global distribution are summarized in Table 2.

Table 2. Details on Orthohepevirus A genotypes.

\begin{tabular}{|c|c|c|c|}
\hline $\begin{array}{l}\text { Genotype }{ }^{1} \\
\text { (Subtypes) }\end{array}$ & Host & Transmission Route & Global Distribution ${ }^{1}$ \\
\hline $\begin{array}{l}\text { HEV-1 } \\
(1 \mathrm{a}-1 \mathrm{~g})\end{array}$ & Human, primates & $\begin{array}{l}\text { Fecal-oral via contaminated } \\
\text { drinking water }\end{array}$ & $\begin{array}{l}\text { Mainly resource poor regions in } \\
\text { India, Pakistan, Bangladesh, } \\
\text { Myanmar, China, Mongolia, } \\
\text { Morocco, Chad, Nigeria }\end{array}$ \\
\hline $\begin{array}{l}\text { HEV-2 } \\
(2 a, 2 b)\end{array}$ & Human, primates & $\begin{array}{l}\text { Fecal-oral via contaminated } \\
\text { drinking water }\end{array}$ & $\begin{array}{l}\text { Mainly resource poor regions in } \\
\text { Mexico, Nigeria }\end{array}$ \\
\hline $\begin{array}{c}\text { HEV-3 } \\
(3 a-3 m, 3 r a)\end{array}$ & $\begin{array}{l}\text { Human, pig, wild } \\
\text { boar, deer, mongoose, } \\
\text { rabbit (3ra), hare } \\
\text { (3ra), rodents }\end{array}$ & $\begin{array}{l}\text { Zoonotic via consumption or } \\
\text { contact of/with contaminated } \\
\text { foodstuffs; parenteral via } \\
\text { contaminated blood donations }\end{array}$ & $\begin{array}{c}\text { Mainly in industrialized countries } \\
\text { such as } \\
\text { USA, Canada, China, Japan, South } \\
\text { Korea, India, Singapore, UK, } \\
\text { Germany, France, Italy, Spain, } \\
\text { Sweden, Switzerland, } \\
\text { Netherlands, Denmark, Hungary }\end{array}$ \\
\hline
\end{tabular}


Table 2. Cont.

\begin{tabular}{|c|c|c|c|}
\hline $\begin{array}{l}\text { Genotype }^{1} \\
\text { (Subtypes) }\end{array}$ & Host & Transmission Route & Global Distribution ${ }^{1}$ \\
\hline $\begin{array}{l}\text { HEV-4 } \\
(4 a-4 i)\end{array}$ & $\begin{array}{l}\text { Human, pig, wild } \\
\text { boar, cow, goat, yak, } \\
\text { Rhesus monkey }\end{array}$ & $\begin{array}{l}\text { Zoonotic via consumption or } \\
\text { contact of/with contaminated } \\
\text { foodstuffs; parenteral via } \\
\text { contaminated blood donations }\end{array}$ & $\begin{array}{l}\text { Mainly in Asian countries such as } \\
\text { China, Mongolia, Japan, South } \\
\text { Korea, Taiwan, Cambodia, India }\end{array}$ \\
\hline $\begin{array}{l}\text { HEV-5 } \\
(5 a)\end{array}$ & Wild boar & Unavailable & Japan \\
\hline $\begin{array}{c}\text { HEV-6 } \\
(6 a)\end{array}$ & Wild boar & Unavailable & Japan \\
\hline $\begin{array}{l}\text { HEV-7 } \\
(7 a)\end{array}$ & $\begin{array}{c}\text { Human, } \\
\text { dromedary camel }\end{array}$ & $\begin{array}{l}\text { Zoonotic, likely via consumption } \\
\text { of camel meat }\end{array}$ & UAE \\
\hline $\begin{array}{l}\text { HEV-8 } \\
(8 a)\end{array}$ & Bactrian camel & Unavailable & China \\
\hline
\end{tabular}

${ }^{1}$ Information according to the International Committee on Taxonomy of Viruses (ICTV) as of September 2020 and Smith et al. 2020 [10].

Moreover, sporadic human infections with rat HEV (Orthohepevirus $C$ ) have been reported $[12,13,144]$. HEV epidemiology shows two differing patterns based on the global distribution of the Orthohepevirus A genotypes [9] (Figure 2). HEV-1 and HEV-2 genotypes are human pathogens that are mostly transmitted via the fecal-oral route in resource poor countries, mainly through contaminated drinking water, with several cases of vertical transmission having also been described [16]. In contrast, infections with HEV-3 and HEV-4 are autochthonous in developed countries and mainly zoonotically acquired via consumption of contaminated food, but parenteral transmission via blood transfusions have also been described [145]. Despite several HEV genotypes, only a single serotype has been reported, which simplifies seroprevalence studies, diagnosis, and vaccination [146-148].

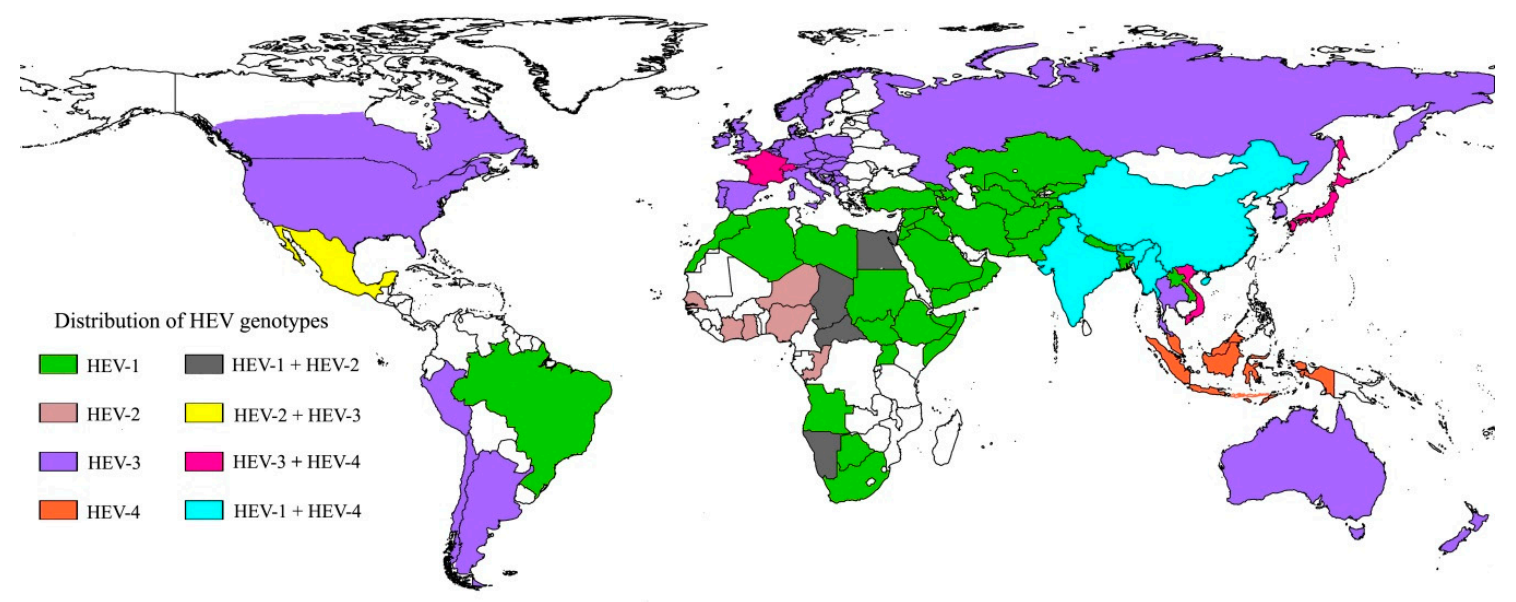

Figure 2. Global HEV genotype distribution. Different colors on the map indicate the distribution of HEV genotypes (HEV-1 through -4) across the globe. The figure was created using SimpleMappr, an online tool to produce publication-quality point maps [149].

The HEV-1 and HEV-2 genotypes are estimated to infect about 20 million people in resource poor countries, resulting in 3.3 million symptomatic cases and 44,000 deaths per year [9]. However, it is believed that these figures are underestimated due to lack of awareness and lack of diagnosis and serological tests [150]. HEV-1 is the main cause of significant recurrent epidemics in resource poor countries in Africa and Asia and isolated small epidemics in Latin America, as well as large outbreaks in India [14,151]. HEV-2 outbreaks were reported in 1986-1987 from rural towns in Morelos 
in Mexico [152], Nigeria, Sudan, and Namibia [79,153-155], and the recent ones reported in Burkina Faso. Studies have shown that HEV-1 and HEV-2 infections occur most frequently in men during their adolescence (15-30 years), and most patients experience acute self-limiting hepatitis [94,100]. In addition, HEV outbreaks were recognized among people living in refugee camps and in emergency shelters after natural disasters [127,139-142]. Few studies have reported human-to-human transmission; however, this needs to be elucidated [156].

HEV-3 and HEV-4 are zoonotically transmitted from pigs, wild boar, deer, and rabbits in developed countries [157], where pigs are the main reservoir, and autochthonous infections are caused by the consumption of undercooked meat [158] or contact with pigs and wild animals [159]. Previously, the cause of HEV-induced hepatitis was considered a disease of resource poor countries, but it has become clear that HEV is also acquired locally in industrialized regions $[160,161]$. A recent review and meta-analysis lists seroprevalence rates of $0.04 \%$ to $52.5 \%$ in these countries, with the highest prevalence reported from France, Poland, and Denmark [162]. HEV is much more frequent than previously thought, with an estimated $>400.000$ infections per year in Germany [163]. HEV-3 is common among pigs worldwide, which constitute the major reservoir for human infections $[164,165]$. HEV-4 is widely distributed in South and East Asia, where both wild and domesticated pigs serve as a reservoir $[10,158,166]$. Infection rates are high in people over 50 years of age $[4,167,168]$, and seroepidemiological studies found no significant differences in HEV-IgG seropositivity according to gender [169]. However, a recent study revealed that men were more frequently infected than women [170]. Other HEV genotypes such as HEV-5 and -6 were found in wild boars, whereas HEV-7 and -8 are present in camels $[143,171-173]$. So far, only HEV-7 has shown a zoonotic potential associated with practices of camel meat consumption in the Middle East [11]. Sporadic reports of human infections with rat HEV (Orthohepevirus C) have also been reported [12,13]. HEV genotypes are selective with unique transmission patterns, pathogenesis [174,175], clinical manifestations in different patient groups, and host adaption.

\section{Diagnosis and Clinical Aspects}

As a large percentage of HEV infections do not present with symptoms, the disease often goes undiagnosed. In individuals presenting with hepatitis, symptoms are indistinguishable from those of hepatitis A. Standard diagnostic tests for hepatitis E include the detection of HEV-specific antibodies, including both anti-HEV IgM and IgG, as well as amplification of the viral genome using conventional PCR or real-time reverse transcription PCR [176]. During the last decades, WHO international standard materials have been developed to assist standardization of NAT and anti-HEV IgG detection assays $[177,178]$. Awareness of the need for HEV testing has been increasing over the last decade, and many countries have begun to implement HEV RNA screening in blood donations [179].

Although the main site of replication for HEV is the liver, non-hepatic replication has been shown in the brain, kidney, placenta, and others [180]. This may explain a series of different extrahepatic manifestations that can occur in infected patients. Neurological manifestations include Guillain-Barré syndrome and neuralgic amyotrophy, while kidney disorders such as cryoglobulinemia and hematological conditions have also been described in association with hepatitis E [181-187]. In addition, deaths due to fulminant hepatitis have been reported in 0.5 to $4 \%$ of patients, and this percentage is known to be higher in people with pre-existing liver disease [188] and among young children [189]. HEV superinfection could additionally influence the outcome and progression of HBV-related liver diseases [190]. Furthermore, severe disease outcomes may occur in pregnant women infected with HEV-1 with studies describing maternal mortality rates $>30 \%$ within the third trimester, mainly due to fulminant hepatic failure [17]. In immunocompromised persons such as solid organ and hematopoietic stem cell transplant recipients, HEV infection may persist. Patients with chronic hepatitis E will often rapidly progress to liver cirrhosis and have an increased mortality rate [158]. There is no approved drug against HEV infection. If initial reduction of immunosuppression does not lead to HEV clearance, off-label treatment for chronic hepatitis $\mathrm{E}$ is indicated with ribavirin. Non-responding 
liver-transplant patients can be further treated with pegylated interferon alfa-2a and pegylated interferon alfa-2b [168]. Several molecules with in vitro antiviral activity against HEV have been described. Repurposed antivirals include 2'-C-methylcytidine (2-CMC) [191], NITD008 and GPC-N114 [192], ciprofloxacin and IFN- $\lambda$ [193], and sofosbuvir [194]. Compound screening studies have revealed plant ethanol extracts from L. mauritiana [195] and L. platyphylla [196], as well as zinc [197], and the small molecule 66E2 [198] as potential antivirals. An FDA-approved drug, deptropine, a histamine H1 receptor antagonist used in asthma treatment, showed anti-HEV activity in cell culture and synergized with ribavirin [199]. Target-guided approaches include peptide conjugated phosphorodiamidate morpholino oligomers (PPMO) [200] and proteasome inhibitor MG132 [201,202] in HEV-1 cell culture, the cyclic peptide CP11, which inhibits interaction of HEV with the ESCRT [203], several inhibitors of nucleotide synthesis, including mycophenolic acid [204], Brequinar, and Leflunomide [205], and the natural compound silvestrol [206]. However, only silvestrol [206] and the hepatitis C virus polymerase inhibitor sofosbuvir [194] advanced to in vivo studies. Unfortunately, sofosbuvir monotherapy failed to prove its potency to reduce HEV viral loads in a phase II pilot trial [207]. Finally, the only developed vaccine against $\mathrm{HEV}$, Hecolin ${ }^{\circledR}$, is thus far only approved in China [20]. However, several other candidates based on the HEV capsid protein are currently being developed using different expression systems, such as baculovirus-infected insect cells [208], prokaryotic systems [209], expression in yeast [210,211], vectored vaccines [212], and chimeric vaccines [213,214]. So far, apart from Hecolin ${ }^{\circledR}$, only two candidates have entered clinical trials $[215,216]$. An effective vaccine is an important step in preventing severe hepatitis E-related liver disease in risk populations such as pregnant women and immunocompromised patients.

\section{Conclusions}

Infection with hepatitis E virus is still an under-reported disease worldwide. However, awareness of the prevalence of this virus has grown exponentially in the last decades. Before and since its discovery, there had been numerous large-scale outbreaks in the developing world with tens of thousands of cases, demonstrating that HEV is the most common cause of viral hepatitis worldwide. While HEV-1 and HEV-2 occur mainly in waterborne epidemics in areas with insufficient hygienic conditions, sporadic cases of HEV-3 and HEV-4, which are transmitted zoonotically or via contaminated blood products in industrialized countries, have confirmed that HEV is not a health burden solely of resource poor regions. Although much effort has been put into elucidating the mechanisms of infection, replication, and pathology of the virus, many questions are still left unanswered, underlining the importance of further research on its virology. This is especially important as hepatitis E infections-depending on the genotype-can cause severe liver disease in risk groups such as pregnant women and immunocompromised persons. With these aspects in mind, it is clear that further research is vital to develop more effective treatment options and approved vaccination strategies.

Author Contributions: T.P.V. and C.-T.B. contributed to the design and wrote the review. S.R.P. and D.H. wrote the first draft. J.H. and H.W. contributed to the section on discovery and history. D.T. and E.S. contributed to the section on virology. R.J. contributed to the section on outbreaks. M.S. and J.J.W. contributed to the section on epidemiology. J.H. and J.W.K.S. contributed to the chapter on diagnosis and clinical aspects. All authors have read and agreed to the published version of the manuscript.

Funding: This research was funded by grants from the German Federal Ministry of Health with regard to a decision of the German Bundestag by the Federal Government (CHED-project grant No: ZMVI1-2518FSB705) and (NiCaDe-project grant No: ZMVI1-2519GHP711), and grants from the German Federal Ministry of Education and Research (BMBF01DP19006A, BMBF01DP17047). D.H. is supported by the Claussen-Simon-Stiftung (Claussen-Simon Foundation; CSF) "Dissertation Plus" program, Germany, and the Fazit-Stiftung "Promotions Stipendium".

Conflicts of Interest: The authors declare no conflict of interest. The funders had no role in the design of the study; in the collection, analyses, or interpretation of data; in the writing of the manuscript; or in the decision to publish the results. 


\section{References}

1. Smith, D.B.; Simmonds, P.; International Committee on the Taxonomy of Viruses Hepeviridae Study Group; Jameel, S.; Emerson, S.U.; Harrison, T.J.; Meng, X.J.; Okamoto, H.; Van der Poel, W.H.M.; Purdy, M.A. Consensus proposals for classification of the family Hepeviridae. J. Gen. Virol. 2014, 95, 2223-2232. [CrossRef] [PubMed]

2. Teshale, E.H.; Hu, D.J. Hepatitis E: Epidemiology and prevention. World J. Hepatol. 2011, 3, $285-291$. [CrossRef] [PubMed]

3. Perez-Gracia, M.T.; Suay-Garcia, B.; Mateos-Lindemann, M.L. Hepatitis E and pregnancy: Current state. Rev. Med. Virol. 2017, 27, e1929. [CrossRef] [PubMed]

4. Dalton, H.R.; Stableforth, W.; Thurairajah, P.; Hazeldine, S.; Remnarace, R.; Usama, W.; Farrington, L.; Hamad, N.; Sieberhagen, C.; Ellis, V.; et al. Autochthonous hepatitis E in Southwest England: Natural history, complications and seasonal variation, and hepatitis $\mathrm{E}$ virus IgG seroprevalence in blood donors, the elderly and patients with chronic liver disease. Eur. J. Gastroenterol. Hepatol. 2008, 20, 784-790. [CrossRef]

5. Kamar, N.; Selves, J.; Mansuy, J.M.; Ouezzani, L.; Peron, J.M.; Guitard, J.; Cointault, O.; Esposito, L.; Abravanel, F.; Danjoux, M.; et al. Hepatitis E virus and chronic hepatitis in organ-transplant recipients. N. Engl. J. Med. 2008, 358, 811-817. [CrossRef]

6. Bai, M.J.; Zhou, N.; Dong, W.; Li, G.X.; Cong, W.; Zhu, X.Q. Seroprevalence and risk factors of hepatitis E virus infection in cancer patients in eastern China. Int. J. Infect. Dis. 2018, 71, 42-47. [CrossRef]

7. Rivero-Juarez, A.; Lopez-Lopez, P.; Frias, M.; Rivero, A. Hepatitis E Infection in HIV-Infected Patients. Front. Microbiol. 2019, 10, 1425. [CrossRef]

8. Li, P.; Liu, J.; Li, Y.; Su, J.; Ma, Z.; Bramer, W.M.; Cao, W.; de Man, R.A.; Peppelenbosch, M.P.; Pan, Q. The global epidemiology of hepatitis E virus infection: A systematic review and meta-analysis. Liver Int. 2020, 40, 1516-1528. [CrossRef]

9. WHO. Hepatitis E: Fact Sheet. 2020. Available online: https://www.who.int/news-room/fact-sheets/detail/ hepatitis-e (accessed on 19 October 2020).

10. Smith, D.B.; Izopet, J.; Nicot, F.; Simmonds, P.; Jameel, S.; Meng, X.-J.; Norder, H.; Okamoto, H.; van der Poel, W.H.M.; Reuter, G.; et al. Update: Proposed reference sequences for subtypes of hepatitis E virus (species Orthohepevirus A). J. Gen. Virol. 2020, 101, 692-698. [CrossRef]

11. Lee, G.H.; Tan, B.H.; Teo, E.C.; Lim, S.G.; Dan, Y.Y.; Wee, A.; Aw, P.P.; Zhu, Y.; Hibberd, M.L.; Tan, C.K.; et al. Chronic Infection With Camelid Hepatitis E Virus in a Liver Transplant Recipient Who Regularly Consumes Camel Meat and Milk. Gastroenterology 2016, 150, 355-357.e353. [CrossRef]

12. Sridhar, S.; Yip, C.C.; Wu, S.; Chew, N.F.; Leung, K.H.; Chan, J.F.; Zhao, P.S.; Chan, W.M.; Poon, R.W.; Tsoi, H.W.; et al. Transmission of rat hepatitis E virus infection to humans in Hong Kong: A clinical and epidemiological analysis. Hepatology 2020. [CrossRef] [PubMed]

13. Andonov, A.; Robbins, M.; Borlang, J.; Cao, J.; Hatchette, T.; Stueck, A.; Deschambault, Y.; Murnaghan, K.; Varga, J.; Johnston, L. Rat Hepatitis E Virus Linked to Severe Acute Hepatitis in an Immunocompetent Patient. J. Infect. Dis. 2019, 220, 951-955. [CrossRef] [PubMed]

14. Khuroo, M.S.; Khuroo, M.S.; Khuroo, N.S. Transmission of Hepatitis E Virus in Developing Countries. Viruses 2016, 8, 253. [CrossRef] [PubMed]

15. Wang, B.; Meng, X.J. Hepatitis E virus: Host tropism and zoonotic infection. Curr. Opin. Microbiol. 2020, 59, 8-15. [CrossRef]

16. Mirazo, S.; Ramos, N.; Mainardi, V.; Gerona, S.; Arbiza, J. Transmission, diagnosis, and management of hepatitis E: An update. Hepatic Med. 2014, 6, 45-59. [CrossRef]

17. Patra, S.; Kumar, A.; Trivedi, S.S.; Puri, M.; Sarin, S.K. Maternal and fetal outcomes in pregnant women with acute hepatitis E virus infection. Ann. Intern. Med. 2007, 147, 28-33. [CrossRef]

18. Gérolami, R.; Moal, V.; Colson, P. Chronic hepatitis E with cirrhosis in a kidney-transplant recipient. N. Engl. J. Med. 2008, 358, 859-860. [CrossRef]

19. Haagsma, E.B.; van den Berg, A.P.; Porte, R.J.; Benne, C.A.; Vennema, H.; Reimerink, J.H.; Koopmans, M.P. Chronic hepatitis E virus infection in liver transplant recipients. Liver Transpl. 2008, 14, 547-553. [CrossRef]

20. Zhu, F.C.; Zhang, J.; Zhang, X.F.; Zhou, C.; Wang, Z.Z.; Huang, S.J.; Wang, H.; Yang, C.L.; Jiang, H.M.; Cai, J.P.; et al. Efficacy and safety of a recombinant hepatitis E vaccine in healthy adults: A large-scale, randomised, double-blind placebo-controlled, phase 3 trial. Lancet 2010, 376, 895-902. [CrossRef] 
21. Arankalle, V.A.; Chadha, M.S.; Tsarev, S.A.; Emerson, S.U.; Risbud, A.R.; Banerjee, K.; Purcell, R.H. Seroepidemiology of water-borne hepatitis in India and evidence for a third enterically-transmitted hepatitis agent. Proc. Natl. Acad. Sci. USA 1994, 91, 3428-3432. [CrossRef]

22. Khuroo, M.S. Hepatitis E: The enterically transmitted non-A, non-B hepatitis. Indian J. Gastroenterol. 1991, 10, 96-100. [CrossRef]

23. Khuroo, M.S. Study of an epidemic of non-A, non-B hepatitis. Possibility of another human hepatitis virus distinct from post-transfusion non-A, non-B type. Am. J. Med. 1980, 68, 818-824. [CrossRef]

24. Balayan, M.S.; Andjaparidze, A.G.; Savinskaya, S.S.; Ketiladze, E.S.; Braginsky, D.M.; Savinov, A.P.; Poleschuk, V.F. Evidence for a virus in non-A, non-B hepatitis transmitted via the fecal-oral route. Intervirology 1983, 20, 23-31. [CrossRef] [PubMed]

25. Tam, A.W.; Smith, M.M.; Guerra, M.E.; Huang, C.C.; Bradley, D.W.; Fry, K.E.; Reyes, G.R. Hepatitis E virus (HEV): Molecular cloning and sequencing of the full-length viral genome. Virology 1991, 185, 120-131. [CrossRef]

26. Reyes, G.R.; Purdy, M.A.; Kim, J.P.; Luk, K.C.; Young, L.M.; Fry, K.E.; Bradley, D.W. Isolation of a cDNA from the virus responsible for enterically transmitted non-A, non-B hepatitis. Science 1990, 247, 1335-1339. [CrossRef]

27. Mast, E.E.; Kuramoto, I.K.; Favorov, M.O.; Schoening, V.R.; Burkholder, B.T.; Shapiro, C.N.; Holland, P.V. Prevalence of and risk factors for antibody to hepatitis E virus seroreactivity among blood donors in Northern California. J. Infect. Dis. 1997, 176, 34-40. [CrossRef] [PubMed]

28. Meng, X.J.; Halbur, P.G.; Shapiro, M.S.; Govindarajan, S.; Bruna, J.D.; Mushahwar, I.K.; Purcell, R.H.; Emerson, S.U. Genetic and experimental evidence for cross-species infection by swine hepatitis E virus. J. Virol. 1998, 72, 9714-9721. [CrossRef] [PubMed]

29. Meng, X.J.; Purcell, R.H.; Halbur, P.G.; Lehman, J.R.; Webb, D.M.; Tsareva, T.S.; Haynes, J.S.; Thacker, B.J.; Emerson, S.U. A novel virus in swine is closely related to the human hepatitis E virus. Proc. Natl. Acad. Sci. USA 1997, 94, 9860-9865. [CrossRef]

30. Bradley, D.; Andjaparidze, A.; Cook, E.H., Jr.; McCaustland, K.; Balayan, M.; Stetler, H.; Velazquez, O.; Robertson, B.; Humphrey, C.; Kane, M.; et al. Aetiological agent of enterically transmitted non-A, non-B hepatitis. J. Gen. Virol. 1988, 69 Pt 3, 731-738. [CrossRef]

31. Graff, J.; Torian, U.; Nguyen, H.; Emerson, S.U. A bicistronic subgenomic mRNA encodes both the ORF2 and ORF3 proteins of hepatitis E virus. J. Virol. 2006, 80, 5919-5926. [CrossRef] [PubMed]

32. Koonin, E.V.; Gorbalenya, A.E.; Purdy, M.A.; Rozanov, M.N.; Reyes, G.R.; Bradley, D.W. Computer-assisted assignment of functional domains in the nonstructural polyprotein of hepatitis E virus: Delineation of an additional group of positive-strand RNA plant and animal viruses. Proc. Natl. Acad. Sci. USA 1992, 89, 8259-8263. [CrossRef] [PubMed]

33. Karpe, Y.A.; Lole, K.S. Deubiquitination activity associated with hepatitis E virus putative papain-like cysteine protease. J. Gen. Virol. 2011, 92, 2088-2092. [CrossRef] [PubMed]

34. Magden, J.; Takeda, N.; Li, T.; Auvinen, P.; Ahola, T.; Miyamura, T.; Merits, A.; Kaariainen, L. Virus-specific mRNA capping enzyme encoded by hepatitis E virus. J. Virol. 2001, 75, 6249-6255. [CrossRef]

35. Karpe, Y.A.; Lole, K.S. RNA 5'-triphosphatase activity of the hepatitis E virus helicase domain. J. Virol. 2010, 84, 9637-9641. [CrossRef] [PubMed]

36. Agrawal, S.; Gupta, D.; Panda, S.K. The $3^{\prime}$ end of hepatitis E virus (HEV) genome binds specifically to the viral RNA-dependent RNA polymerase (RdRp). Virology 2001, 282, 87-101. [CrossRef] [PubMed]

37. Parvez, M.K. Molecular characterization of hepatitis E virus ORF1 gene supports a papain-like cysteine protease (PCP)-domain activity. Virus Res. 2013, 178, 553-556. [CrossRef]

38. Parvez, M.K.; Khan, A.A. Molecular modeling and analysis of hepatitis E virus (HEV) papain-like cysteine protease. Virus Res. 2014, 179, 220-224. [CrossRef]

39. Smith, D.B.; Vanek, J.; Ramalingam, S.; Johannessen, I.; Templeton, K.; Simmonds, P. Evolution of the hepatitis E virus hypervariable region. J. Gen. Virol. 2012, 93, 2408-2418. [CrossRef]

40. Lhomme, S.; Nicot, F.; Jeanne, N.; Dimeglio, C.; Roulet, A.; Lefebvre, C.; Carcenac, R.; Manno, M.; Dubois, M.; Peron, J.M.; et al. Insertions and Duplications in the Polyproline Region of the Hepatitis E Virus. Front. Microbiol. 2020, 11, 1. [CrossRef]

41. Jameel, S.; Zafrullah, M.; Ozdener, M.H.; Panda, S.K. Expression in animal cells and characterization of the hepatitis E virus structural proteins. J. Virol. 1996, 70, 207-216. [CrossRef] 
42. Torresi, J.; Li, F.; Locarnini, S.A.; Anderson, D.A. Only the non-glycosylated fraction of hepatitis E virus capsid (open reading frame 2) protein is stable in mammalian cells. J. Gen. Virol. 1999, 80 Pt 5, 1185-1188. [CrossRef]

43. Zafrullah, M.; Ozdener, M.H.; Kumar, R.; Panda, S.K.; Jameel, S. Mutational analysis of glycosylation, membrane translocation, and cell surface expression of the hepatitis E virus ORF2 protein. J. Virol. 1999, 73, 4074-4082. [CrossRef] [PubMed]

44. Zhou, Y.H.; Purcell, R.H.; Emerson, S.U. A truncated ORF2 protein contains the most immunogenic site on ORF2: Antibody responses to non-vaccine sequences following challenge of vaccinated and non-vaccinated macaques with hepatitis E virus. Vaccine 2005, 23, 3157-3165. [CrossRef]

45. Yin, X.; Ying, D.; Lhomme, S.; Tang, Z.; Walker, C.M.; Xia, N.; Zheng, Z.; Feng, Z. Origin, antigenicity, and function of a secreted form of ORF2 in hepatitis E virus infection. Proc. Natl. Acad. Sci. USA 2018, 115, 4773-4778. [CrossRef]

46. Montpellier, C.; Wychowski, C.; Sayed, I.M.; Meunier, J.C.; Saliou, J.M.; Ankavay, M.; Bull, A.; Pillez, A.; Abravanel, F.; Helle, F.; et al. Hepatitis E Virus Lifecycle and Identification of 3 Forms of the ORF2 Capsid Protein. Gastroenterology 2018, 154, 211-223.e218. [CrossRef]

47. Nagashima, S.; Takahashi, M.; Jirintai, S.; Tanaka, T.; Yamada, K.; Nishizawa, T.; Okamoto, H. A PSAP motif in the ORF3 protein of hepatitis E virus is necessary for virion release from infected cells. J. Gen. Virol. 2011, 92, 269-278. [CrossRef]

48. Nagashima, S.; Takahashi, M.; Jirintai, S.; Tanaka, T.; Nishizawa, T.; Yasuda, J.; Okamoto, H. Tumour susceptibility gene 101 and the vacuolar protein sorting pathway are required for the release of hepatitis $\mathrm{E}$ virions. J. Gen. Virol. 2011, 92, 2838-2848. [CrossRef]

49. Kannan, H.; Fan, S.; Patel, D.; Bossis, I.; Zhang, Y.J. The hepatitis E virus open reading frame 3 product interacts with microtubules and interferes with their dynamics. J. Virol. 2009, 83, 6375-6382. [CrossRef] [PubMed]

50. Nagashima, S.; Jirintai, S.; Takahashi, M.; Kobayashi, T.; Tanggis; Nishizawa, T.; Kouki, T.; Yashiro, T.; Okamoto, H. Hepatitis E virus egress depends on the exosomal pathway, with secretory exosomes derived from multivesicular bodies. J. Gen. Virol. 2014, 95, 2166-2175. [CrossRef] [PubMed]

51. Gouttenoire, J.; Pollán, A.; Abrami, L.; Oechslin, N.; Mauron, J.; Matter, M.; Oppliger, J.; Szkolnicka, D.; Dao Thi, V.L.; van der Goot, F.G.; et al. Palmitoylation mediates membrane association of hepatitis E virus ORF3 protein and is required for infectious particle secretion. PLoS Pathog. 2018, 14, e1007471. [CrossRef]

52. Chandra, V.; Kar-Roy, A.; Kumari, S.; Mayor, S.; Jameel, S. The hepatitis E virus ORF3 protein modulates epidermal growth factor receptor trafficking, STAT3 translocation, and the acute-phase response. J. Virol. 2008, 82, 7100-7110. [CrossRef] [PubMed]

53. He, M.; Wang, M.; Huang, Y.; Peng, W.; Zheng, Z.; Xia, N.; Xu, J.; Tian, D. The ORF3 Protein of Genotype 1 Hepatitis E Virus Suppresses TLR3-induced NF-kappaB Signaling via TRADD and RIP1. Sci. Rep. 2016, 6, 27597. [CrossRef] [PubMed]

54. Xu, J.; Wu, F.; Tian, D.; Wang, J.; Zheng, Z.; Xia, N. Open reading frame 3 of genotype 1 hepatitis E virus inhibits nuclear factor-kappaappa B signaling induced by tumor necrosis factor-alpha in human A549 lung epithelial cells. PLoS ONE 2014, 9, e100787. [CrossRef]

55. Ding, Q.; Heller, B.; Capuccino, J.M.; Song, B.; Nimgaonkar, I.; Hrebikova, G.; Contreras, J.E.; Ploss, A. Hepatitis E virus ORF3 is a functional ion channel required for release of infectious particles. Proc. Natl. Acad. Sci. USA 2017, 114, 1147-1152. [CrossRef]

56. Nagashima, S.; Takahashi, M.; Kobayashi, T.; Nishizawa, T.; Nishiyama, T.; Primadharsini, P.P.; Okamoto, H. Characterization of the Quasi-Enveloped Hepatitis E Virus Particles Released by the Cellular Exosomal Pathway. J. Virol. 2017, 91, e00822-17. [CrossRef]

57. Marion, O.; Lhomme, S.; Nayrac, M.; Dubois, M.; Pucelle, M.; Requena, M.; Migueres, M.; Abravanel, F.; Peron, J.M.; Carrere, N.; et al. Hepatitis E virus replication in human intestinal cells. Gut 2019, 69, 901-910. [CrossRef] [PubMed]

58. Smith, W. The action of bile salts on viruses. J. Pathol. Bacteriol. 1939, 48, 557-571. [CrossRef]

59. Kalia, M.; Chandra, V.; Rahman, S.A.; Sehgal, D.; Jameel, S. Heparan sulfate proteoglycans are required for cellular binding of the hepatitis E virus ORF2 capsid protein and for viral infection. J. Virol. 2009, 83, 12714-12724. [CrossRef] 
60. Zhou, Y.; Emerson, S.P. 302 Heat shock cognate protein 70 may mediate the entry of hepatitis E virus into host cells. J. Clin. Virol. 2006, 36, S155. [CrossRef]

61. Shiota, T.; Li, T.C.; Nishimura, Y.; Yoshizaki, S.; Sugiyama, R.; Shimojima, M.; Saijo, M.; Shimizu, H.; Suzuki, R.; Wakita, T.; et al. Integrin alpha3 is involved in non-enveloped hepatitis E virus infection. Virology 2019, 536, 119-124. [CrossRef]

62. Holla, P.; Ahmad, I.; Ahmed, Z.; Jameel, S. Hepatitis E virus enters liver cells through a dynamin-2, clathrin and membrane cholesterol-dependent pathway. Traffic 2015, 16, 398-416. [CrossRef]

63. Yin, X.; Ambardekar, C.; Lu, Y.; Feng, Z. Distinct Entry Mechanisms for Nonenveloped and Quasi-Enveloped Hepatitis E Viruses. J. Virol. 2016, 90, 4232-4242. [CrossRef] [PubMed]

64. Debing, Y.; Moradpour, D.; Neyts, J.; Gouttenoire, J. Update on hepatitis E virology: Implications for clinical practice. J. Hepatol. 2016, 65, 200-212. [CrossRef] [PubMed]

65. Perttila, J.; Spuul, P.; Ahola, T. Early secretory pathway localization and lack of processing for hepatitis E virus replication protein pORF1. J. Gen. Virol. 2013, 94, 807-816. [CrossRef] [PubMed]

66. Rehman, S.; Kapur, N.; Durgapal, H.; Panda, S.K. Subcellular localization of hepatitis E virus (HEV) replicase. Virology 2008, 370, 77-92. [CrossRef] [PubMed]

67. Wissing, M.H.; Bruggemann, Y.; Steinmann, E.; Todt, D. Virus-Host Cell Interplay during Hepatitis E Virus Infection. Trends Microbiol. 2020. [CrossRef]

68. Emerson, S.U.; Zhang, M.; Meng, X.J.; Nguyen, H.; St Claire, M.; Govindarajan, S.; Huang, Y.K.; Purcell, R.H. Recombinant hepatitis $\mathrm{E}$ virus genomes infectious for primates: Importance of capping and discovery of a cis-reactive element. Proc. Natl. Acad. Sci. USA 2001, 98, 15270-15275. [CrossRef]

69. Shukla, P.; Nguyen, H.T.; Torian, U.; Engle, R.E.; Faulk, K.; Dalton, H.R.; Bendall, R.P.; Keane, F.E.; Purcell, R.H.; Emerson, S.U. Cross-species infections of cultured cells by hepatitis E virus and discovery of an infectious virus-host recombinant. Proc. Natl. Acad. Sci. USA 2011, 108, 2438-2443. [CrossRef]

70. Scholz, J.; Bachlein, C.; Gadicherla, A.K.; Falkenhagen, A.; Tausch, S.H.; Johne, R. Establishment of a Plasmid-Based Reverse Genetics System for the Cell Culture-Adapted Hepatitis E Virus Genotype 3c Strain 47832c. Pathogens 2020, 9, 157. [CrossRef]

71. Córdoba, L.; Feagins, A.R.; Opriessnig, T.; Cossaboom, C.M.; Dryman, B.A.; Huang, Y.W.; Meng, X.J. Rescue of a genotype 4 human hepatitis $\mathrm{E}$ virus from cloned cDNA and characterization of intergenotypic chimeric viruses in cultured human liver cells and in pigs. J. Gen. Virol. 2012, 93, 2183-2194. [CrossRef]

72. Todt, D.; Friesland, M.; Moeller, N.; Praditya, D.; Kinast, V.; Bruggemann, Y.; Knegendorf, L.; Burkard, T.; Steinmann, J.; Burm, R.; et al. Robust hepatitis E virus infection and transcriptional response in human hepatocytes. Proc. Natl. Acad. Sci. USA 2020, 117, 1731-1741. [CrossRef] [PubMed]

73. Purcell, R.H.; Nguyen, H.; Shapiro, M.; Engle, R.E.; Govindarajan, S.; Blackwelder, W.C.; Wong, D.C.; Prieels, J.P.; Emerson, S.U. Pre-clinical immunogenicity and efficacy trial of a recombinant hepatitis E vaccine. Vaccine 2003, 21, 2607-2615. [CrossRef]

74. Tsarev, S.A.; Emerson, S.U.; Tsareva, T.S.; Yarbough, P.O.; Lewis, M.; Govindarajan, S.; Reyes, G.R.; Shapiro, M.; Purcell, R.H. Variation in course of hepatitis E in experimentally infected cynomolgus monkeys. J. Infect. Dis. 1993, 167, 1302-1306. [CrossRef] [PubMed]

75. Halbur, P.G.; Kasorndorkbua, C.; Gilbert, C.; Guenette, D.; Potters, M.B.; Purcell, R.H.; Emerson, S.U.; Toth, T.E.; Meng, X.J. Comparative pathogenesis of infection of pigs with hepatitis E viruses recovered from a pig and a human. J. Clin. Microbiol. 2001, 39, 918-923. [CrossRef]

76. Feagins, A.R.; Opriessnig, T.; Huang, Y.W.; Halbur, P.G.; Meng, X.J. Cross-species infection of specific-pathogen-free pigs by a genotype 4 strain of human hepatitis E virus. J. Med. Virol. 2008, 80, 1379-1386. [CrossRef]

77. Allweiss, L.; Gass, S.; Giersch, K.; Groth, A.; Kah, J.; Volz, T.; Rapp, G.; Schöbel, A.; Lohse, A.W.; Polywka, S.; et al. Human liver chimeric mice as a new model of chronic hepatitis E virus infection and preclinical drug evaluation. J. Hepatol. 2016, 64, 1033-1040. [CrossRef] [PubMed]

78. Sayed, I.M.; Verhoye, L.; Cocquerel, L.; Abravanel, F.; Foquet, L.; Montpellier, C.; Debing, Y.; Farhoudi, A.; Wychowski, C.; Dubuisson, J.; et al. Study of hepatitis E virus infection of genotype 1 and 3 in mice with humanised liver. Gut 2017, 66, 920-929. [CrossRef] [PubMed]

79. Maila, H.T.; Bowyer, S.M.; Swanepoel, R. Identification of a new strain of hepatitis E virus from an outbreak in Namibia in 1995. J. Gen. Virol. 2004, 85, 89-95. [CrossRef] [PubMed] 
80. Viswanathan, R. Infectious hepatitis in Delhi (1955-56): A critical study-epidemiology. 1957. Natl. Med. J. India 2013, 26, 362-377. [PubMed]

81. Belabbes, E.H.; Bouguermouh, A.; Benatallah, A.; Illoul, G. Epidemic non-A, non-B viral hepatitis in Algeria: Strong evidence for its spreading by water. J. Med. Virol. 1985, 16, 257-263. [CrossRef]

82. Hla, M.; Myint Myint, S.; Tun, K.; Thein-Maung, M.; Khin Maung, T. A clinical and epidemiological study of an epidemic of non-A non-B hepatitis in Rangoon. Am. J. Trop. Med. Hyg. 1985, 34, 1183-1189. [CrossRef]

83. Isaacson, M.; Frean, J.; He, J.; Seriwatana, J.; Innis, B.L. An outbreak of hepatitis E in Northern Namibia, 1983. Am. J. Trop. Med. Hyg. 2000, 62, 619-625. [CrossRef]

84. Sarthou, J.L.; Budkowska, A.; Sharma, M.D.; Lhuillier, M.; Pillot, J. Characterization of an antigen-antibody system associated with epidemic non-A, non-B hepatitis in West Africa and experimental transmission of an infectious agent to primates. Ann. Inst. Pasteur Virol. 1986, 137E, 225-232. [CrossRef]

85. Favorov, M.O.; Khukhlovich, P.A.; Zairov, G.K.; Listovskaia, E.K.; Arakelov, S.A. [Clinico-epidemiological characteristics and diagnosis of viral non-A, non-B hepatitis with fecal and oral mechanisms of transmission of the infection]. Vopr. Virusol. 1986, 31, 65-69. (In Russian)

86. Albetkova, A.; Drobeniuc, J.; Yashina, T.; Musabaev, E.; Robertson, B.; Nainan, O.; Favorov, M. Characterization of hepatitis E virus from outbreak and sporadic cases in Turkmenistan. J. Med. Virol. 2007, 79, 1696-1702. [CrossRef] [PubMed]

87. Byskov, J.; Wouters, J.S.; Sathekge, T.J.; Swanepoel, R. An outbreak of suspected water-borne epidemic non-A non-B hepatitis in northern Botswana with a high prevalence of hepatitis B carriers and hepatitis delta markers among patients. Trans. R. Soc. Trop. Med. Hyg. 1989, 83, 110-116. [CrossRef]

88. Velazquez, O.; Stetler, H.C.; Avila, C.; Ornelas, G.; Alvarez, C.; Hadler, S.C.; Bradley, D.W.; Sepulveda, J. Epidemic transmission of enterically transmitted non-A, non-B hepatitis in Mexico, 1986-1987. JAMA 1990, 263, 3281-3285. [CrossRef]

89. Mushahwar, I.K.; Dawson, G.J.; Bile, K.M.; Magnius, L.O. Serological studies of an enterically transmitted non-A, non-B hepatitis in Somalia. J. Med. Virol. 1993, 40, 218-221. [CrossRef]

90. Pal, P.K.; Haldar, A.; Bhattacharya, S.K. An outbreak of viral hepatitis in a housing complex of north Calcutta. J. Commun. Dis. 1994, 26, 88-91.

91. Tsega, E.; Krawczynski, K.; Hansson, B.G.; Nordenfelt, E.; Negusse, Y.; Alemu, W.; Bahru, Y. Outbreak of acute hepatitis E virus infection among military personnel in northern Ethiopia. J. Med. Virol. 1991, 34, 232-236. [CrossRef]

92. Uchida, T.; Aye, T.T.; Ma, X.; Iida, F.; Shikata, T.; Ichikawa, M.; Rikihisa, T.; Win, K.M. An epidemic outbreak of hepatitis E in Yangon of Myanmar: Antibody assay and animal transmission of the virus. Acta Pathol. Jpn. 1993, 43, 94-98. [CrossRef] [PubMed]

93. Naik, S.R.; Aggarwal, R.; Salunke, P.N.; Mehrotra, N.N. A large waterborne viral hepatitis E epidemic in Kanpur, India. Bull. World Health Organ. 1992, 70, 597-604. [PubMed]

94. Zhuang, H.; Cao, X.Y.; Liu, C.B.; Wang, G.M. Epidemiology of hepatitis E in China. Gastroenterol. Jpn. 1991, 26 (Suppl. 3), 135-138. [CrossRef] [PubMed]

95. Bi, S.L.; Purdy, M.A.; McCaustland, K.A.; Margolis, H.S.; Bradley, D.W. The sequence of hepatitis E virus isolated directly from a single source during an outbreak in China. Virus Res. 1993, 28, 233-247. [CrossRef]

96. Corwin, A.; Jarot, K.; Lubis, I.; Nasution, K.; Suparmawo, S.; Sumardiati, A.; Widodo, S.; Nazir, S.; Orndorff, G.; Choi, Y.; et al. Two years' investigation of epidemic hepatitis E virus transmission in West Kalimantan (Borneo), Indonesia. Trans. R. Soc. Trop. Med. Hyg. 1995, 89, 262-265. [CrossRef]

97. Rab, M.A.; Bile, M.K.; Mubarik, M.M.; Asghar, H.; Sami, Z.; Siddiqi, S.; Dil, A.S.; Barzgar, M.A.; Chaudhry, M.A.; Burney, M.I. Water-borne hepatitis E virus epidemic in Islamabad, Pakistan: A common source outbreak traced to the malfunction of a modern water treatment plant. Am. J. Trop. Med. Hyg. 1997, 57, 151-157. [CrossRef]

98. Corwin, A.L.; Khiem, H.B.; Clayson, E.T.; Pham, K.S.; Vo, T.T.; Vu, T.Y.; Cao, T.T.; Vaughn, D.; Merven, J.; Richie, T.L.; et al. A waterborne outbreak of hepatitis E virus transmission in southwestern Vietnam. Am. J. Trop. Med. Hyg. 1996, 54, 559-562. [CrossRef]

99. Benjelloun, S.; Bahbouhi, B.; Bouchrit, N.; Cherkaoui, L.; Hda, N.; Mahjour, J.; Benslimane, A. Seroepidemiological study of an acute hepatitis E outbreak in Morocco. Res. Virol. 1997, 148, $279-287$. [CrossRef] 
100. Aggarwal, R.; Kumar, R.; Pal, R.; Naik, S.; Semwal, S.N.; Naik, S.R. Role of travel as a risk factor for hepatitis E virus infection in a disease-endemic area. Indian J. Gastroenterol. 2002, 21, 14-18.

101. Sedyaningsih-Mamahit, E.R.; Larasati, R.P.; Laras, K.; Sidemen, A.; Sukri, N.; Sabaruddin, N.; Didi, S.; Saragih, J.M.; Myint, K.S.; Endy, T.P.; et al. First documented outbreak of hepatitis E virus transmission in Java, Indonesia. Trans. R. Soc. Trop. Med. Hyg. 2002, 96, 398-404. [CrossRef]

102. Bryan, J.P.; Iqbal, M.; Tsarev, S.; Malik, I.A.; Duncan, J.F.; Ahmed, A.; Khan, A.; Khan, A.; Rafiqui, A.R.; Purcell, R.H.; et al. Epidemic of hepatitis E in a military unit in Abbotrabad, Pakistan. Am. J. Trop. Med. Hyg. 2002, 67, 662-668. [CrossRef] [PubMed]

103. Banerjee, A.; Sahni, A.K.; Rajiva; Nagendra, A.; Saiprasad, G.S. Outbreak of Viral Hepatitis E in a Regimental Training Centre. Med. J. Armed Forces India 2005, 61, 326-329. [CrossRef]

104. Goumba, A.I.; Konamna, X.; Komas, N.P. Clinical and epidemiological aspects of a hepatitis E outbreak in Bangui, Central African Republic. BMC Infect. Dis. 2011, 11, 93. [CrossRef] [PubMed]

105. Rayis, D.A.; Jumaa, A.M.; Gasim, G.I.; Karsany, M.S.; Adam, I. An outbreak of hepatitis E and high maternal mortality at Port Sudan, Eastern Sudan. Pathog. Glob. Health 2013, 107, 66-68. [CrossRef]

106. Swain, S.K.; Baral, P.; Hutin, Y.J.; Rao, T.V.; Murhekar, M.; Gupte, M.D. A hepatitis E outbreak caused by a temporary interruption in a municipal water treatment system, Baripada, Orissa, India, 2004. Trans. R. Soc. Trop. Med. Hyg. 2010, 104, 66-69. [CrossRef] [PubMed]

107. Rec, W.E. Hepatitis E, Chad. Wkly. Epidemiol. Rec. 2004, 79, 313.

108. Al-Nasrawi, K.K.; Al Diwan, J.K.; Al-Hadithi, T.S.; Saleh, A.M. Viral hepatitis E outbreak in Al-Sadr city, Baghdad, Iraq. East. Mediterr. Health J. 2010, 16, 1128-1132. [CrossRef]

109. Sarguna, P.; Rao, A.; Sudha Ramana, K.N. Outbreak of acute viral hepatitis due to hepatitis E virus in Hyderabad. Indian J. Med. Microbiol. 2007, 25, 378-382. [CrossRef]

110. Guthmann, J.P.; Klovstad, H.; Boccia, D.; Hamid, N.; Pinoges, L.; Nizou, J.Y.; Tatay, M.; Diaz, F.; Moren, A.; Grais, R.F.; et al. A large outbreak of hepatitis E among a displaced population in Darfur, Sudan, 2004: The role of water treatment methods. Clin. Infect. Dis. 2006, 42, 1685-1691. [CrossRef]

111. Boccia, D.; Guthmann, J.P.; Klovstad, H.; Hamid, N.; Tatay, M.; Ciglenecki, I.; Nizou, J.Y.; Nicand, E.; Guerin, P.J. High mortality associated with an outbreak of hepatitis E among displaced persons in Darfur, Sudan. Clin. Infect. Dis. 2006, 42, 1679-1684. [CrossRef]

112. Khuroo, M.S.; Khuroo, M.S. Seroepidemiology of a second epidemic of hepatitis E in a population that had recorded first epidemic 30 years before and has been under surveillance since then. Hepatol. Int. 2010, 4, 494-499. [CrossRef] [PubMed]

113. Shata, M.T.; Daef, E.A.; Zaki, M.E.; Abdelwahab, S.F.; Marzuuk, N.M.; Sobhy, M.; Rafaat, M.; Abdelbaki, L.; Nafeh, M.A.; Hashem, M.; et al. Protective role of humoral immune responses during an outbreak of hepatitis E in Egypt. Trans. R. Soc. Trop. Med. Hyg. 2012, 106, 613-618. [CrossRef] [PubMed]

114. Gerbi, G.B.; Williams, R.; Bakamutumaho, B.; Liu, S.; Downing, R.; Drobeniuc, J.; Kamili, S.; Xu, F.; Holmberg, S.D.; Teshale, E.H. Hepatitis E as a cause of acute jaundice syndrome in northern Uganda, 2010-2012. Am. J. Trop. Med. Hyg. 2015, 92, 411-414. [CrossRef]

115. Vivek, R.; Nihal, L.; Illiayaraja, J.; Reddy, P.K.; Sarkar, R.; Eapen, C.E.; Kang, G. Investigation of an epidemic of Hepatitis E in Nellore in south India. Trop. Med. Int. Health 2010, 15, 1333-1339. [CrossRef]

116. Teshale, E.H.; Howard, C.M.; Grytdal, S.P.; Handzel, T.R.; Barry, V.; Kamili, S.; Drobeniuc, J.; Okware, S.; Downing, R.; Tappero, J.W.; et al. Hepatitis E epidemic, Uganda. Emerg. Infect. Dis. 2010, 16, 126-129. [CrossRef]

117. Teshale, E.H.; Grytdal, S.P.; Howard, C.; Barry, V.; Kamili, S.; Drobeniuc, J.; Hill, V.R.; Okware, S.; Hu, D.J.; Holmberg, S.D. Evidence of person-to-person transmission of hepatitis E virus during a large outbreak in Northern Uganda. Clin. Infect. Dis. 2010, 50, 1006-1010. [CrossRef] [PubMed]

118. Howard, C.M.; Handzel, T.; Hill, V.R.; Grytdal, S.P.; Blanton, C.; Kamili, S.; Drobeniuc, J.; Hu, D.; Teshale, E. Novel risk factors associated with hepatitis E virus infection in a large outbreak in northern Uganda: Results from a case-control study and environmental analysis. Am. J. Trop. Med. Hyg. 2010, 83, 1170-1173. [CrossRef]

119. Gurley, E.S.; Hossain, M.J.; Paul, R.C.; Sazzad, H.M.; Islam, M.S.; Parveen, S.; Faruque, L.I.; Husain, M.; Ara, K.; Jahan, Y.; et al. Outbreak of hepatitis E in urban Bangladesh resulting in maternal and perinatal mortality. Clin. Infect. Dis. 2014, 59, 658-665. [CrossRef] 
120. Cummings, M.J.; Wamala, J.F.; Komakech, I.; Lukwago, L.; Malimbo, M.; Omeke, M.E.; Mayer, D.; Bakamutumaho, B. Hepatitis E in Karamoja, Uganda, 2009-2012: Epidemiology and challenges to control in a setting of semi-nomadic pastoralism. Trans. R. Soc. Trop. Med. Hyg. 2014, 108, 648-655. [CrossRef]

121. Harun-Or-Rashid, M.; Akbar, S.M.; Takahashi, K.; Al-Mahtab, M.; Khan, M.S.; Alim, M.A.; Ekram, A.R.; Khan, M.M.; Arai, M.; Mishiro, S. Epidemiological and molecular analyses of a non-seasonal outbreak of acute icteric hepatitis E in Bangladesh. J. Med. Virol. 2013, 85, 1369-1376. [CrossRef]

122. Majumdar, M.; Singh, M.P.; Pujhari, S.K.; Bhatia, D.; Chawla, Y.; Ratho, R.K. Hepatitis E virus antigen detection as an early diagnostic marker: Report from India. J. Med. Virol. 2013, 85, 823-827. [CrossRef] [PubMed]

123. Karna, R.; Hazam, R.K.; Borkakoti, J.; Kumar, A.; Kar, P. A 5-year Single-Center Experience of Hepatitis E Virus Infection During Pregnancy. J. Clin. Exp. Hepatol. 2020, 10, 135-138. [CrossRef] [PubMed]

124. Tambe, M.; Patil, S.M.D.; Bhagwat, V. Investigation of an Outbreak of Hepatitis 'E' in a Rural Area of Dhule District in Maharashtra. JKIMSU 2015, 4, 109-114.

125. Ahmed, J.A.; Moturi, E.; Spiegel, P.; Schilperoord, M.; Burton, W.; Kassim, N.H.; Mohamed, A.; Ochieng, M.; Nderitu, L.; Navarro-Colorado, C.; et al. Hepatitis E outbreak, Dadaab refugee camp, Kenya, 2012. Emerg. Infect. Dis. 2013, 19, 1010-1012. [CrossRef]

126. Tricou, V.; Bouscaillou, J.; Laghoe-Nguembe, G.L.; Bere, A.; Konamna, X.; Selekon, B.; Nakoune, E.; Kazanji, M.; Komas, N.P. Hepatitis E virus outbreak associated with rainfall in the Central African Republic in 2008-2009. BMC Infect. Dis. 2020, 20, 260. [CrossRef]

127. Center for Global Health, CDC. Prevention. Investigation of hepatitis E outbreak among refugees - Upper Nile, South Sudan, 2012-2013. MMWR Morb. Mortal Wkly. Rep. 2013, 62, 581-586.

128. Awsathi, S.; Rawat, V.; Rawat, C.M.; Semwal, V.; Bartwal, S.J. Epidemiological investigation of the jaundice outbreak in lalkuan, nainital district, uttarakhand. Indian J. Community Med. 2014, 39, 94-97. [CrossRef]

129. Maurice, D.; Abassora, M.; Marcelin, N.; Richard, N. First documented outbreak of Hepatitis E in Northern Cameroon. Ann. Trop. Med. PH 2013, 6, 682-683. [CrossRef]

130. Khan, A.I.; Salimuzzaman, M.; Islam, M.T.; Afrad, M.H.; Shirin, T.; Jony, M.H.K.; Alam, M.A.; Rahman, M.; Flora, M.S.; Qadri, F. Nationwide Hospital-Based Seroprevalence of Hepatitis A and Hepatitis E Virus in Bangladesh. Ann. Glob. Health 2020, 86, 29. [CrossRef]

131. Goel, A.; Padmaprakash, K.V.; Benjamin, M.; Katiyar, H.; Aggarwal, R. Temporal profile of HEV RNA concentration in blood and stool from patients with acute uncomplicated hepatitis $\mathrm{E}$ in a region with genotype 1 predominance. J. Viral. Hepat. 2020, 27, 631-637. [CrossRef]

132. Spina, A.; Lenglet, A.; Beversluis, D.; de Jong, M.; Vernier, L.; Spencer, C.; Andayi, F.; Kamau, C.; Vollmer, S.; Hogema, B.; et al. A large outbreak of Hepatitis E virus genotype 1 infection in an urban setting in Chad likely linked to household level transmission factors, 2016-2017. PLoS ONE 2017, 12, e0188240. [CrossRef] [PubMed]

133. WHO. Weekly Bulletin on Outbreaks and Other Emergencies; WHO: Geneva, Switzerland, 2017.

134. Paul, R.C.; Nazneen, A.; Banik, K.C.; Sumon, S.A.; Paul, K.K.; Akram, A.; Uzzaman, M.S.; Iqbal, T.; Tejada-Strop, A.; Kamili, S.; et al. Hepatitis E as a cause of adult hospitalization in Bangladesh: Results from an acute jaundice surveillance study in six tertiary hospitals, 2014-2017. PLoS Negl. Trop. Dis. 2020, 14, e0007586. [CrossRef]

135. WHO. Weekly Bulletin on Outbreaks and Other Emergencies; WHO: Geneva, Switzerland, 2018.

136. Salman, M.; Ul Mustafa, Z.; Asif, N. Hepatitis E outbreak in the province of Punjab, Pakistan: A call for action. Infect. Dis. (Lond.) 2019, 51, 633-634. [CrossRef] [PubMed]

137. Bustamante, N.D.; Matyenyika, S.R.; Miller, L.A.; Goers, M.; Katjiuanjo, P.; Ndiitodino, K.; Ndevaetela, E.E.; Kaura, U.; Nyarko, K.M.; Kahuika-Crentsil, L.; et al. Notes from the Field: Nationwide Hepatitis E Outbreak Concentrated in Informal Settlements-Namibia, 2017-2020. MMWR Morb. Mortal. Wkly. Rep. 2020, 69, 355-357. [CrossRef]

138. Carratala, A.; Joost, S. Population density and water balance influence the global occurrence of hepatitis E epidemics. Sci. Rep. 2019, 9, 10042. [CrossRef] [PubMed]

139. Hakim, M.S.; Wang, W.; Bramer, W.M.; Geng, J.; Huang, F.; de Man, R.A.; Peppelenbosch, M.P.; Pan, Q. The global burden of hepatitis E outbreaks: A systematic review. Liver Int. 2017, 37, 19-31. [CrossRef] 
140. Lagare, A.; Ibrahim, A.; Ousmane, S.; Issaka, B.; Zaneidou, M.; Kadade, G.; Testa, J. Outbreak of Hepatitis E Virus Infection in Displaced Persons Camps in Diffa Region, Niger, 2017. Am. J. Trop. Med. Hyg. 2018, 99, 1055-1057. [CrossRef]

141. Azman, A.S.; Bouhenia, M.; Iyer, A.S.; Rumunu, J.; Laku, R.L.; Wamala, J.F.; Rodriguez-Barraquer, I.; Lessler, J.; Gignoux, E.; Luquero, F.J.; et al. High Hepatitis E Seroprevalence Among Displaced Persons in South Sudan. Am. J. Trop. Med. Hyg. 2017, 96, 1296-1301. [CrossRef]

142. Guerrero-Latorre, L.; Carratala, A.; Rodriguez-Manzano, J.; Calgua, B.; Hundesa, A.; Girones, R. Occurrence of water-borne enteric viruses in two settlements based in Eastern Chad: Analysis of hepatitis E virus, hepatitis A virus and human adenovirus in water sources. J. Water Health 2011, 9, 515-524. [CrossRef]

143. Woo, P.C.; Lau, S.K.; Teng, J.L.; Tsang, A.K.; Joseph, M.; Wong, E.Y.; Tang, Y.; Sivakumar, S.; Xie, J.; Bai, R.; et al. New hepatitis E virus genotype in camels, the Middle East. Emerg. Infect. Dis. 2014, 20, 1044-1048. [CrossRef]

144. Sridhar, S.; Yip, C.C.Y.; Wu, S.; Cai, J.; Zhang, A.J.; Leung, K.H.; Chung, T.W.H.; Chan, J.F.W.; Chan, W.M.; Teng, J.L.L.; et al. Rat Hepatitis E Virus as Cause of Persistent Hepatitis after Liver Transplant. Emerg. Infect. Dis. 2018, 24, 2241-2250. [CrossRef]

145. Pischke, S.; Hiller, J.; Lutgehetmann, M.; Polywka, S.; Rybczynski, M.; Ayuk, F.; Lohse, A.W. Blood-borne Hepatitis E Virus Transmission: A Relevant Risk for Immunosuppressed Patients. Clin. Infect. Dis. 2016, 63, 569-570. [CrossRef] [PubMed]

146. Gu, Y.; Tang, X.; Zhang, X.; Song, C.; Zheng, M.; Wang, K.; Zhang, J.; Ng, M.H.; Hew, C.L.; Li, S.; et al. Structural basis for the neutralization of hepatitis E virus by a cross-genotype antibody. Cell Res. 2015, 25, 604-620. [CrossRef]

147. Zhang, J.; Shih, J.W.; Wu, T.; Li, S.W.; Xia, N.S. Development of the hepatitis E vaccine: From bench to field. Semin. Liver Dis. 2013, 33, 79-88. [CrossRef] [PubMed]

148. Wu, X.; Chen, P.; Lin, H.; Hao, X.; Liang, Z. Hepatitis E virus: Current epidemiology and vaccine. Hum. Vaccines Immunother. 2016, 12, 2603-2610. [CrossRef]

149. Shorthouse, D.P. SimpleMappr, An Online Tool to Produce Publication-Quality Point Maps. 2010. Available online: http://www.simplemappr.net (accessed on 17 September 2020).

150. Webb, G.W.; Dalton, H.R. Hepatitis E: An underestimated emerging threat. Ther. Adv. Infect. Dis. 2019, 6, 2049936119837162. [CrossRef] [PubMed]

151. Khuroo, M.S.; Khuroo, M.S.; Khuroo, N.S. Hepatitis E: Discovery, global impact, control and cure. World J. Gastroenterol. 2016, 22, 7030-7045. [CrossRef]

152. Huang, C.C.; Nguyen, D.; Fernandez, J.; Yun, K.Y.; Fry, K.E.; Bradley, D.W.; Tam, A.W.; Reyes, G.R. Molecular cloning and sequencing of the Mexico isolate of hepatitis E virus (HEV). Virology 1992, 191, 550-558. [CrossRef]

153. Dimeglio, C.; Kania, D.; Mantono, J.M.; Kagone, T.; Zida, S.; Tassembedo, S.; Dicko, A.; Tinto, B.; Yaro, S.; Hien, H.; et al. Hepatitis E Virus Infections among Patients with Acute Febrile Jaundice in Burkina Faso. Viruses 2019, 11, 554. [CrossRef]

154. Buisson, Y.; Grandadam, M.; Nicand, E.; Cheval, P.; van Cuyck-Gandre, H.; Innis, B.; Rehel, P.; Coursaget, P.; Teyssou, R.; Tsarev, S. Identification of a novel hepatitis E virus in Nigeria. J. Gen. Virol. 2000, 81, 903-909. [CrossRef] [PubMed]

155. Nicand, E.; Armstrong, G.L.; Enouf, V.; Guthmann, J.P.; Guerin, J.P.; Caron, M.; Nizou, J.Y.; Andraghetti, R. Genetic heterogeneity of hepatitis E virus in Darfur, Sudan, and neighboring Chad. J. Med. Virol. 2005, 77, 519-521. [CrossRef] [PubMed]

156. Aggarwal, R.; Naik, S.R. Hepatitis E: Intrafamilial transmission versus waterborne spread. J. Hepatol. 1994, 21, 718-723. [CrossRef]

157. Kamar, N.; Dalton, H.R.; Abravanel, F.; Izopet, J. Hepatitis E virus infection. Clin. Microbiol. Rev. 2014, 27, 116-138. [CrossRef] [PubMed]

158. Lu, L.; Li, C.; Hagedorn, C.H. Phylogenetic analysis of global hepatitis E virus sequences: Genetic diversity, subtypes and zoonosis. Rev. Med. Virol. 2006, 16, 5-36. [CrossRef] [PubMed]

159. Adlhoch, C.; Avellon, A.; Baylis, S.A.; Ciccaglione, A.R.; Couturier, E.; de Sousa, R.; Epstein, J.; Ethelberg, S.; Faber, M.; Feher, A.; et al. Hepatitis E virus: Assessment of the epidemiological situation in humans in Europe, 2014/15. J. Clin. Virol. 2016, 82, 9-16. [CrossRef] 
160. Aspinall, E.J.; Couturier, E.; Faber, M.; Said, B.; Ijaz, S.; Tavoschi, L.; Takkinen, J.; Adlhoch, C.; The Country, E. Hepatitis E virus infection in Europe: Surveillance and descriptive epidemiology of confirmed cases, 2005 to 2015. Eurosurveillance 2017, 22, 30561. [CrossRef]

161. Yapa, C.M.; Furlong, C.; Rosewell, A.; Ward, K.A.; Adamson, S.; Shadbolt, C.; Kok, J.; Tracy, S.L.; Bowden, S.; Smedley, E.J.; et al. First reported outbreak of locally acquired hepatitis E virus infection in Australia. Med. J. Aust. 2016, 204, 274. [CrossRef]

162. Wilhelm, B.; Waddell, L.; Greig, J.; Young, I. Systematic review and meta-analysis of the seroprevalence of hepatitis E virus in the general population across non-endemic countries. PLoS ONE 2019, 14, e0216826. [CrossRef]

163. Faber, M.; Willrich, N.; Schemmerer, M.; Rauh, C.; Kuhnert, R.; Stark, K.; Wenzel, J.J. Hepatitis E virus seroprevalence, seroincidence and seroreversion in the German adult population. J. Viral Hepat. 2018, 25, 752-758. [CrossRef]

164. Sooryanarain, H.; Meng, X.J. Swine hepatitis E virus: Cross-species infection, pork safety and chronic infection. Virus Res. 2020, 284, 197985. [CrossRef]

165. Pavio, N.; Doceul, V.; Bagdassarian, E.; Johne, R. Recent knowledge on hepatitis E virus in Suidae reservoirs and transmission routes to human. Vet. Res. 2017, 48, 78. [CrossRef]

166. Zhu, Y.M.; Dong, S.J.; Si, F.S.; Yu, R.S.; Li, Z.; Yu, X.M.; Zou, S.X. Swine and human hepatitis E virus (HEV) infection in China. J. Clin. Virol. 2011, 52, 155-157. [CrossRef] [PubMed]

167. Dalton, H.R.; Fellows, H.J.; Gane, E.J.; Wong, P.; Gerred, S.; Schroeder, B.; Croxson, M.C.; Garkavenko, O. Hepatitis E in new zealand. J. Gastroenterol. Hepatol. 2007, 22, 1236-1240. [CrossRef] [PubMed]

168. Dalton, H.R.; Kamar, N.; Baylis, S.A.; Moradpour, D.; Wedemeyer, H.; Negro, F. EASL Clinical Practice Guidelines on hepatitis E virus infection. J. Hepatol. 2018, 68, 1256-1271. [CrossRef]

169. Faber, M.S.; Wenzel, J.J.; Jilg, W.; Thamm, M.; Hohle, M.; Stark, K. Hepatitis E virus seroprevalence among adults, Germany. Emerg. Infect. Dis. 2012, 18, 1654-1657. [CrossRef]

170. Mahrt, H.; Schemmerer, M.; Behrens, G.; Leitzmann, M.; Jilg, W.; Wenzel, J.J. Continuous decline of hepatitis E virus seroprevalence in southern Germany despite increasing notifications, 2003-2015. Emerg. Microbes Infect. 2018, 7, 133. [CrossRef] [PubMed]

171. Takahashi, M.; Nishizawa, T.; Sato, H.; Sato, Y.; Jirintai; Nagashima, S.; Okamoto, H. Analysis of the full-length genome of a hepatitis E virus isolate obtained from a wild boar in Japan that is classifiable into a novel genotype. J. Gen. Virol. 2011, 92, 902-908. [CrossRef]

172. Woo, P.C.; Lau, S.K.; Teng, J.L.; Cao, K.Y.; Wernery, U.; Schountz, T.; Chiu, T.H.; Tsang, A.K.; Wong, P.C.; Wong, E.Y.; et al. New Hepatitis E Virus Genotype in Bactrian Camels, Xinjiang, China, 2013. Emerg. Infect. Dis. 2016, 22, 2219-2221. [CrossRef]

173. Takahashi, M.; Nishizawa, T.; Sato, Y.; Miyazaki, S.; Aikawa, T.; Ashida, K.; Tamaru, T.; Oguro, K.; Hayakawa, F.; Matsuoka, H.; et al. Prevalence and genotype/subtype distribution of hepatitis E virus (HEV) among wild boars in Japan: Identification of a genotype 5 HEV strain. Virus Res. 2020, 287, 198106. [CrossRef]

174. Kamar, N.; Bendall, R.; Legrand-Abravanel, F.; Xia, N.S.; Ijaz, S.; Izopet, J.; Dalton, H.R. Hepatitis, E. Lancet 2012, 379, 2477-2488. [CrossRef]

175. Lhomme, S.; Marion, O.; Abravanel, F.; Chapuy-Regaud, S.; Kamar, N.; Izopet, J. Hepatitis E Pathogenesis. Viruses 2016, 8, 212. [CrossRef] [PubMed]

176. Jothikumar, N.; Cromeans, T.L.; Robertson, B.H.; Meng, X.J.; Hill, V.R. A broadly reactive one-step real-time RT-PCR assay for rapid and sensitive detection of hepatitis E virus. J. Virol. Methods 2006, 131, 65-71. [CrossRef] [PubMed]

177. Baylis, S.A.; Hanschmann, K.M.; Blumel, J.; Nubling, C.M.; Group, H.E.V.C.S. Standardization of hepatitis E virus (HEV) nucleic acid amplification technique-based assays: An initial study to evaluate a panel of HEV strains and investigate laboratory performance. J. Clin. Microbiol. 2011, 49, 1234-1239. [CrossRef] [PubMed]

178. Ferguson, M.; Walker, D.; Mast, E.; Fields, H. Report of a collaborative study to assess the suitability of a reference reagent for antibodies to hepatitis E virus. Biologicals 2002, 30, 43-48. [CrossRef]

179. Boland, F.; Martinez, A.; Pomeroy, L.; O’Flaherty, N. Blood Donor Screening for Hepatitis E Virus in the European Union. Transfus. Med. Hemother. 2019, 46, 95-103. [CrossRef]

180. Pischke, S.; Hartl, J.; Pas, S.D.; Lohse, A.W.; Jacobs, B.C.; Van der Eijk, A.A. Hepatitis E virus: Infection beyond the liver? J. Hepatol. 2017, 66, 1082-1095. [CrossRef] 
181. van den Berg, B.; van der Eijk, A.A.; Pas, S.D.; Hunter, J.G.; Madden, R.G.; Tio-Gillen, A.P.; Dalton, H.R.; Jacobs, B.C. Guillain-Barré syndrome associated with preceding hepatitis E virus infection. Neurology 2014, 82, 491-497. [CrossRef]

182. Stevens, O.; Claeys, K.G.; Poesen, K.; Saegeman, V.; Van Damme, P. Diagnostic Challenges and Clinical Characteristics of Hepatitis E Virus-Associated Guillain-Barré Syndrome. JAMA Neurol. 2017, 74, $26-33$. [CrossRef]

183. van Eijk, J.J.; Madden, R.G.; van der Eijk, A.A.; Hunter, J.G.; Reimerink, J.H.; Bendall, R.P.; Pas, S.D.; Ellis, V.; van Alfen, N.; Beynon, L.; et al. Neuralgic amyotrophy and hepatitis E virus infection. Neurology 2014, 82, 498-503. [CrossRef]

184. Kamar, N.; Weclawiak, H.; Guilbeau-Frugier, C.; Legrand-Abravanel, F.; Cointault, O.; Ribes, D.; Esposito, L.; Cardeau-Desangles, I.; Guitard, J.; Sallusto, F.; et al. Hepatitis E virus and the kidney in solid-organ transplant patients. Transplantation 2012, 93, 617-623. [CrossRef]

185. Masood, I.; Rafiq, A.; Majid, Z. Hepatitis E presenting with thrombocytopaenia. Trop. Dr. 2014, 44, $219-220$. [CrossRef] [PubMed]

186. Ahmad, B.S.; Ahmad, A.; Jamil, S.; Abubakar Mohsin Ehsanullah, S.A.; Munir, A. Severe haemolysis and renal failure precipitated by hepatitis E virus in G6PD Deficient patient: A case report. J. Pak. Med. Assoc. 2018, 68, 1397-1399. [PubMed]

187. Abid, S.; Khan, A.H. Severe hemolysis and renal failure in glucose-6-phosphate dehydrogenase deficient patients with hepatitis E. Am. J. Gastroenterol. 2002, 97, 1544-1547. [CrossRef] [PubMed]

188. Acharya, S.K.; Sharma, P.K.; Singh, R.; Mohanty, S.K.; Madan, K.; Kumar Jha, J.; Panda, S.K. Hepatitis E virus (HEV) infection in patients with cirrhosis is associated with rapid decompensation and death. J. Hepatol. 2007, 46, 387-394. [CrossRef] [PubMed]

189. Sharapov, M.B.; Favorov, M.O.; Yashina, T.L.; Brown, M.S.; Onischenko, G.G.; Margolis, H.S.; Chorba, T.L. Acute viral hepatitis morbidity and mortality associated with hepatitis E virus infection: Uzbekistan surveillance data. BMC Infect. Dis. 2009, 9, 35. [CrossRef] [PubMed]

190. Hoan, N.X.; Tong, H.V.; Hecht, N.; Sy, B.T.; Marcinek, P.; Meyer, C.G.; Song le, H.; Toan, N.L.; Kurreck, J.; Kremsner, P.G.; et al. Hepatitis E Virus Superinfection and Clinical Progression in Hepatitis B Patients. EBioMedicine 2015, 2, 2080-2086. [CrossRef]

191. Qu, C.; Xu, L.; Yin, Y.; Peppelenbosch, M.P.; Pan, Q.; Wang, W. Nucleoside analogue 2'-C-methylcytidine inhibits hepatitis E virus replication but antagonizes ribavirin. Arch. Virol. 2017, 162, 2989-2996. [CrossRef] [PubMed]

192. Netzler, N.E.; Enosi Tuipulotu, D.; Vasudevan, S.G.; Mackenzie, J.M.; White, P.A. Antiviral Candidates for Treating Hepatitis E Virus Infection. Antimicrob. Agents Chemother. 2019, 63, e00003-19. [CrossRef]

193. Nishiyama, T.; Kobayashi, T.; Jirintai, S.; Kii, I.; Nagashima, S.; Prathiwi Primadharsini, P.; Nishizawa, T.; Okamoto, H. Screening of novel drugs for inhibiting hepatitis E virus replication. J. Virol. Methods 2019, 270, 1-11. [CrossRef]

194. Dao Thi, V.L.; Debing, Y.; Wu, X.; Rice, C.M.; Neyts, J.; Moradpour, D.; Gouttenoire, J. Sofosbuvir Inhibits Hepatitis E Virus Replication In Vitro and Results in an Additive Effect When Combined With Ribavirin. Gastroenterology 2016, 150, 82-85.e84. [CrossRef]

195. Jin, S.E.; Kim, J.E.; Kim, S.Y.; Park, B.J.; Song, Y.J. An ethanol extract of Lysimachia mauritiana exhibits inhibitory activity against hepatitis E virus genotype 3 replication. J. Microbiol. 2017, 55, 984-988. [CrossRef]

196. Park, G.; Parveen, A.; Kim, J.E.; Cho, K.H.; Kim, S.Y.; Park, B.J.; Song, Y.J. Spicatoside A derived from Liriope platyphylla root ethanol extract inhibits hepatitis E virus genotype 3 replication in vitro. Sci. Rep. 2019, 9, 4397. [CrossRef]

197. Kaushik, N.; Subramani, C.; Anang, S.; Muthumohan, R.; Shalimar; Nayak, B.; Ranjith-Kumar, C.T.; Surjit, M. Zinc Salts Block Hepatitis E Virus Replication by Inhibiting the Activity of Viral RNA-Dependent RNA Polymerase. J. Virol. 2017, 91. [CrossRef]

198. Madhvi, A.; Hingane, S.; Srivastav, R.; Joshi, N.; Subramani, C.; Muthumohan, R.; Khasa, R.; Varshney, S.; Kalia, M.; Vrati, S.; et al. A screen for novel hepatitis C virus RdRp inhibitor identifies a broad-spectrum antiviral compound. Sci. Rep. 2017, 7, 5816. [CrossRef]

199. Qu, C.; Li, Y.; Li, Y.; Yu, P.; Li, P.; Donkers, J.M.; van de Graaf, S.F.J.; de Man, R.A.; Peppelenbosch, M.P.; Pan, Q. FDA-drug screening identifies deptropine inhibiting hepatitis E virus involving the NF-kB-RIPK1-caspase axis. Antiviral Res. 2019, 170, 104588. [CrossRef] [PubMed] 
200. Nan, Y.; Ma, Z.; Kannan, H.; Stein, D.A.; Iversen, P.I.; Meng, X.J.; Zhang, Y.J. Inhibition of hepatitis E virus replication by peptide-conjugated morpholino oligomers. Antivir. Res. 2015, 120, 134-139. [CrossRef]

201. Karpe, Y.A.; Meng, X.J. Hepatitis E virus replication requires an active ubiquitin-proteasome system. J. Virol. 2012, 86, 5948-5952. [CrossRef] [PubMed]

202. Xu, L.; Zhou, X.; Peppelenbosch, M.P.; Pan, Q. Inhibition of hepatitis E virus replication by proteasome inhibitor is nonspecific. Arch. Virol. 2015, 160, 435-439. [CrossRef]

203. Anang, S.; Kaushik, N.; Hingane, S.; Kumari, A.; Gupta, J.; Asthana, S.; Shalimar; Nayak, B.; Ranjith-Kumar, C.T.; Surjit, M. Potent Inhibition of Hepatitis E Virus Release by a Cyclic Peptide Inhibitor of the Interaction between Viral Open Reading Frame 3 Protein and Host Tumor Susceptibility Gene 101. J. Virol. 2018, 92, e00684-18. [CrossRef] [PubMed]

204. Wang, Y.; Zhou, X.; Debing, Y.; Chen, K.; Van Der Laan, L.J.; Neyts, J.; Janssen, H.L.; Metselaar, H.J.; Peppelenbosch, M.P.; Pan, Q. Calcineurin inhibitors stimulate and mycophenolic acid inhibits replication of hepatitis E virus. Gastroenterology 2014, 146, 1775-1783. [CrossRef]

205. Wang, Y.; Wang, W.; Xu, L.; Zhou, X.; Shokrollahi, E.; Felczak, K.; van der Laan, L.J.; Pankiewicz, K.W.; Sprengers, D.; Raat, N.J.; et al. Cross Talk between Nucleotide Synthesis Pathways with Cellular Immunity in Constraining Hepatitis E Virus Replication. Antimicrob. Agents Chemother. 2016, 60, 2834-2848. [CrossRef] [PubMed]

206. Todt, D.; Moeller, N.; Praditya, D.; Kinast, V.; Friesland, M.; Engelmann, M.; Verhoye, L.; Sayed, I.M.; Behrendt, P.; Dao Thi, V.L.; et al. The natural compound silvestrol inhibits hepatitis E virus (HEV) replication in vitro and in vivo. Antivir. Res. 2018, 157, 151-158. [CrossRef] [PubMed]

207. Cornberg, M.; Pischke, S.; Muller, T.; Behrendt, P.; Piecha, F.; Benckert, J.; Todt, D.; Steinmann, E.; Papkalla, A.; von Karpowitz, M.; et al. Sofosbuvir monotherapy fails to achieve HEV RNA elimination in patients with chronic hepatitis E-The HepNet SofE pilot study. J. Hepatol. 2020, 73, 696-699. [CrossRef] [PubMed]

208. Shrestha, M.P.; Scott, R.M.; Joshi, D.M.; Mammen, M.P., Jr.; Thapa, G.B.; Thapa, N.; Myint, K.S.; Fourneau, M.; Kuschner, R.A.; Shrestha, S.K.; et al. Safety and efficacy of a recombinant hepatitis E vaccine. N. Engl. J. Med. 2007, 356, 895-903. [CrossRef]

209. Dong, C.; Meng, J.H. [Expression, purification and immunogenicity of a novel hepatitis E virus-like particle]. Xi Bao Yu Fen Zi Mian Yi Xue Za Zhi 2006, 22, 339-342.

210. Su, C.X.; Gu, M.R.; Zhang, P.; Jin, Z.J.; Meng, F.H.; Chen, E.J.; Yang, Z.; Liu, Y.; Wang, Y.C. [Expression of ORF2 protein of HEV genotype IV in Hansenula polymorpha]. Sheng Wu Gong Cheng Xue Bao 2007, 23, 73-78.

211. Tong, Y.; Zhan, M.; Lu, J.; Bai, Y.; Bi, S. [Immunogenicity of recombinant HEV ORF2 protein expressed in pichia pastoris]. Zhonghua Shi Yan He Lin Chuang Bing Du Xue Za Zhi 2002, 16, 23-26.

212. Jiménez de Oya, N.; Escribano-Romero, E.; Blázquez, A.B.; Lorenzo, M.; Martín-Acebes, M.A.; Blasco, R.; Saiz, J.C. Characterization of hepatitis E virus recombinant ORF2 proteins expressed by vaccinia viruses. J. Virol. 2012, 86, 7880-7886. [CrossRef]

213. Xiang, K.; Kusov, Y.; Ying, G.; Yan, W.; Shan, Y.; Jinyuan, W.; Na, Y.; Yan, Z.; Hongjun, L.; Maosheng, S. A Recombinant HAV Expressing a Neutralization Epitope of HEV Induces Immune Response against HAV and HEV in Mice. Viruses 2017, 9, 260. [CrossRef]

214. Gao, Y.; Su, Q.; Yi, Y.; Jia, Z.; Wang, H.; Lu, X.; Qiu, F.; Bi, S. Enhanced mucosal immune responses induced by a combined candidate mucosal vaccine based on Hepatitis A virus and Hepatitis E virus structural proteins linked to tuftsin. PLoS ONE 2015, 10, e0123400. [CrossRef]

215. Andrews, J. U.S. Military sponsored vaccine trials and la resistance in Nepal. Am. J. Bioeth. 2005, 5, W1-W3. [CrossRef] [PubMed]

216. Cao, Y.F.; Tao, H.; Hu, Y.M.; Shi, C.B.; Wu, X.; Liang, Q.; Chi, C.P.; Li, L.; Liang, Z.L.; Meng, J.H.; et al. A phase 1 randomized open-label clinical study to evaluate the safety and tolerability of a novel recombinant hepatitis E vaccine. Vaccine 2017, 35, 5073-5080. [CrossRef] [PubMed]

Publisher's Note: MDPI stays neutral with regard to jurisdictional claims in published maps and institutional affiliations. 